\title{
The quantity-quality transition in Asia
}

Mark R. Montgomery

Population Council

Mary Arends-Kuenning

Cem Mete

Follow this and additional works at: https://knowledgecommons.popcouncil.org/departments_sbsr-pgy

Part of the Demography, Population, and Ecology Commons

How does access to this work benefit you? Let us know!

\section{Recommended Citation}

Montgomery, Mark R., Mary Arends-Kuenning, and Cem Mete. 1999. "The quantity-quality transition in Asia," Policy Research Division Working Paper no. 123. New York: Population Council. Verson of record: https://www.jstor.org/stable/3115218 


\section{The $Q$ uantity- $Q$ uality Transition in Asia}

M ark R. Montgomery

$M$ ary Arends-Kuenning

Cem Mete

1999 No. 123 


\title{
The Quantity-Quality Transition in Asia
}

\author{
Mark R. Montgomery \\ Mary Arends-Kuenning \\ Cem Mete
}

Mark R. Montgomery is Associate Professor of Economics, State University of New York at Stony Brook, and Senior Associate, Policy Research Division, Population Council. His e-mail address is mmontgomery@popcouncil.org. Mary Arends-Kuenning is Assistant Professor of Agricultural and Consumer Economics at the University of Illinois, Urbana-Champaign. Cem Mete is a graduate student in the Department of Economics, SUNY-Stony Brook.

The authors thank Cynthia Lloyd for helpful comments. The research reported here was supported by the Rockefeller Foundation through its "Investing in Children: New Research Frontiers" grant to the Population Council. 


\begin{abstract}
Societies in which fertility is falling and human capital investment per child is increasing are experiencing a "quantity-quality" transition. Such transitions imply, over the long term, both slower rates of labor force growth and higher levels of human capital per worker. They are fundamental to economic development. Yet, these transitions are neither automatic nor selfpropelling. Their momentum depends on competing forces acting at both the family and the macroeconomic levels; the balance can easily tip against further transition.
\end{abstract}

Family decisions about schooling are largely motivated by its private economic returns. These returns are determined in labor markets, and here the logic of supply and demand applies. When families decide to invest more deeply in their children, they collectively produce right-ward shifts in the supply of educated young labor. If other things are held fixed, the rate of return to schooling should then fall, and this, in turn, should dampen parental enthusiasm for further educational investments. Reductions in the rate of return should also weaken the case for continued reductions in fertility. Unless they are counterbalanced by other forces, such negative feedbacks would tend to bring a quantity-quality transition to a halt.

The aim of this paper is to explore both the negative and positive feedbacks that have affected the quantity-quality transition in Asia. We assemble the leading hypotheses and evidence on the macroeconomic forces, both domestic and international, that could influence returns to schooling. We also examine family factors, giving particular attention to the intergenerational links that seem to have maintained the momentum of the Asian transition. Our conclusion is that negative feedbacks associated with increases in the relative supplies of educated labor have been largely offset by beneficial macroeconomic change (resulting from increases in the stock of physical capital, substantial technological change, and trade) and by powerful family-level effects that, over the generations, have continued to propel the transition.

This material may not be reproduced in any form without written permission from the authors. 
One can hardly imagine macroeconomic development being sustained without support from a quantity-quality transition, during which families decrease their fertility and increase their human capital investments in children. The reductions in fertility are expressed, after a lag, in slower rates of labor force growth. Greater schooling investments per child translate into higher levels of human capital per worker. In this way, the substitution of quality for quantity in family strategies helps to guide the macroeconomy toward higher income per worker.

Yet, quantity-quality transitions cannot be regarded as automatic or selfpropelling mechanisms. Their operation depends on competing forces acting at both the family and the macroeconomic levels, and the balance can easily tip against further transition. Consider family decisions about schooling, which are largely motivated by its private economic returns. ${ }^{1}$ These returns are determined in labor markets, and here the logic of supply and demand applies. When families decide to invest more deeply in their children, they collectively produce rightward shifts in the supply of educated young labor. If other things are held constant, the rate of return to schooling should then fall, and this, in turn, should dampen parental enthusiasm for further educational investments. Reductions in the rate of return should also weaken the case for continued reductions in fertility. Unless they are counterbalanced by other forces, such negative feedbacks would tend to bring a quantity-quality transition to a halt.

In the well-documented case of Korea (Kim and Topel 1995), economic returns to tertiary schooling fell considerably during the 1980s, evidently in response to such supply shifts. Similar changes have been detected in the late 1980s for Taiwan (Huang 1998). What is the record elsewhere? Are high returns generally maintained in spite of shifts in the supply of skills? If so, is this due to the spillover benefits of trade, technological change that sustains the demand for skilled labor, or capital accumulation that complements skills? Perhaps government investments in the quality of education also play a role, in that such investments are made more easily where the growth rate of the school-age population is lower (Mason 1993; Mason and Campbell 1993). 
The aim of this paper is to explore both the negative and positive feedbacks that have affected the quantity-quality transition in Asia. We assemble the leading hypotheses and evidence on the macroeconomic forces, both domestic and international, that could influence returns to schooling. We also examine family factors, giving particular attention to the intergenerational links that seem to have maintained the momentum of the Asian transition.

The paper is organized as follows. The first section outlines the microeconomic perspective on fertility and schooling that motivates the study. We then briefly review the record of fertility decline and rising school enrollments in the countries of East and Southeast Asia and in a set of comparison countries in South and South-Central Asia. Following this review, we present evidence on the key variables that link the macroeconomic forces to family-level decisions: rates of return to primary, secondary, and tertiary schooling. Rate-ofreturn calculations from Psacharopoulos $(1985,1994)$ are examined, together with supplementary evidence drawn from other sources. We discuss the macroeconomic factors that are thought to influence these rates of return and test several of the leading hypotheses with country-level data.

We then turn to the family-level evidence, presenting estimates of fertility and children's schooling from Pakistan, Bangladesh, Indonesia, Malaysia, the Philippines, Thailand, and Taiwan. The issue of interest in this section is whether, even with the aggregate returns to schooling held constant, powerful family-level forces might continue to promote a quantity-quality transition. We find strong evidence of such positive feedbacks. The final section presents a discussion of our results and the conclusions.

\section{A Microeconomic Perspective}

Figure 1 displays the quantity-quality transitions in the regions of Asia on which we focus. The experiences of countries in East and Southeast Asia are shown in Figure 1a; those of selected South and South-Central Asian countries 
Figure 1a The Quantity-Quality Transition, 1970-85

East and Southeast Asian Countries

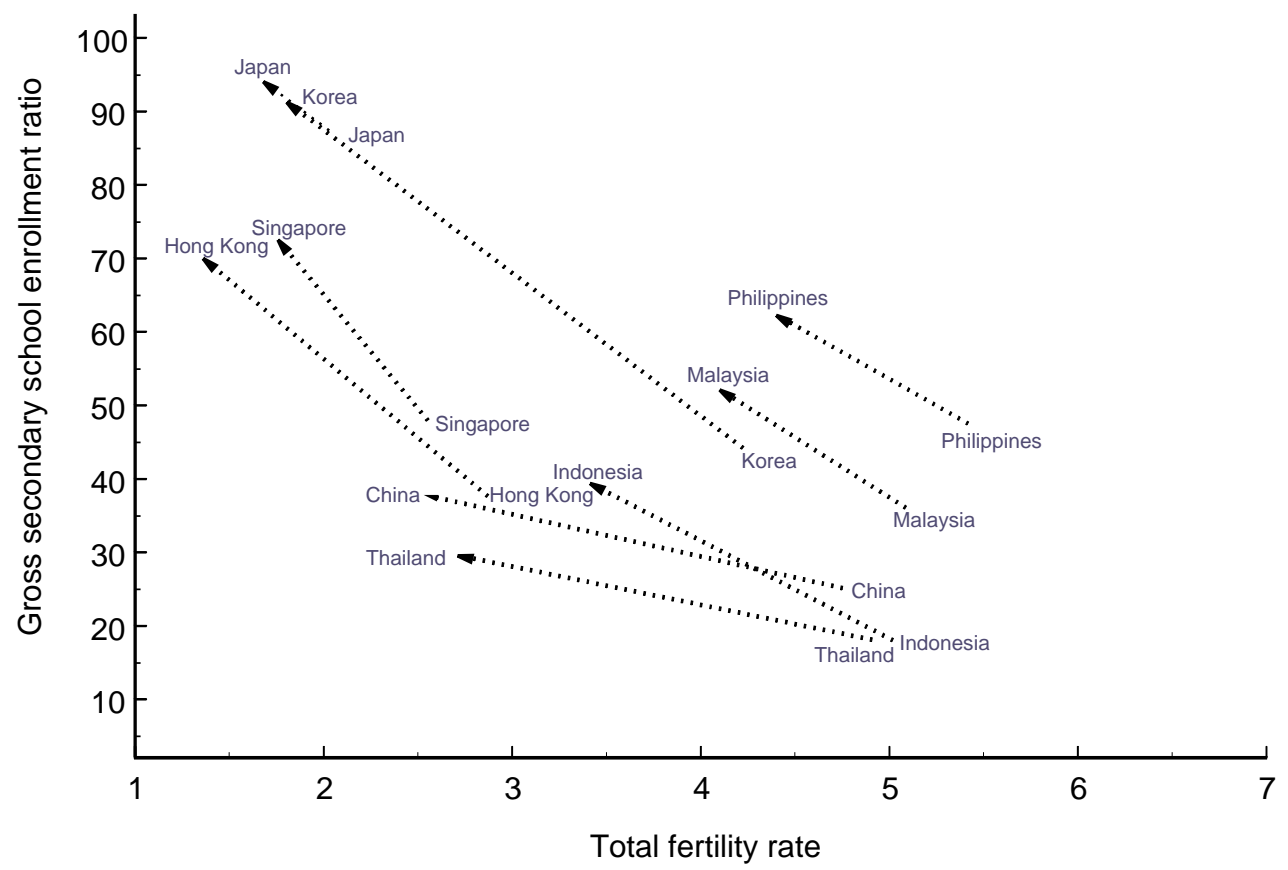

are depicted in Figure 1b. In each of these figures, the total fertility rate is on the horizontal axis, and one measure of human capital investment—secondary school enrollment ratios - is displayed on the vertical. Each country is represented by two points, corresponding to 1970 and 1985, with an arrow indicating the direction of change. As can be seen, profound changes in fertility and schooling were underway in East and Southeast Asia over the 15-year period considered in the figure. The case of Korea is perhaps most remarkable, combining deep reductions in fertility with impressive increases in secondary school enrollments. Other countries have also made notable strides, as in the cases of Thailand and China with respect to fertility, and Hong Kong and Singapore with respect to enrollments.

Turning to the other Asian countries in Figure 1b, we see changes of the same nature but of lesser extent. ${ }^{2}$ Pakistan registered a modest decline in fertility, 
Figure 1b The Quantity-Quality Transition, 1970-85

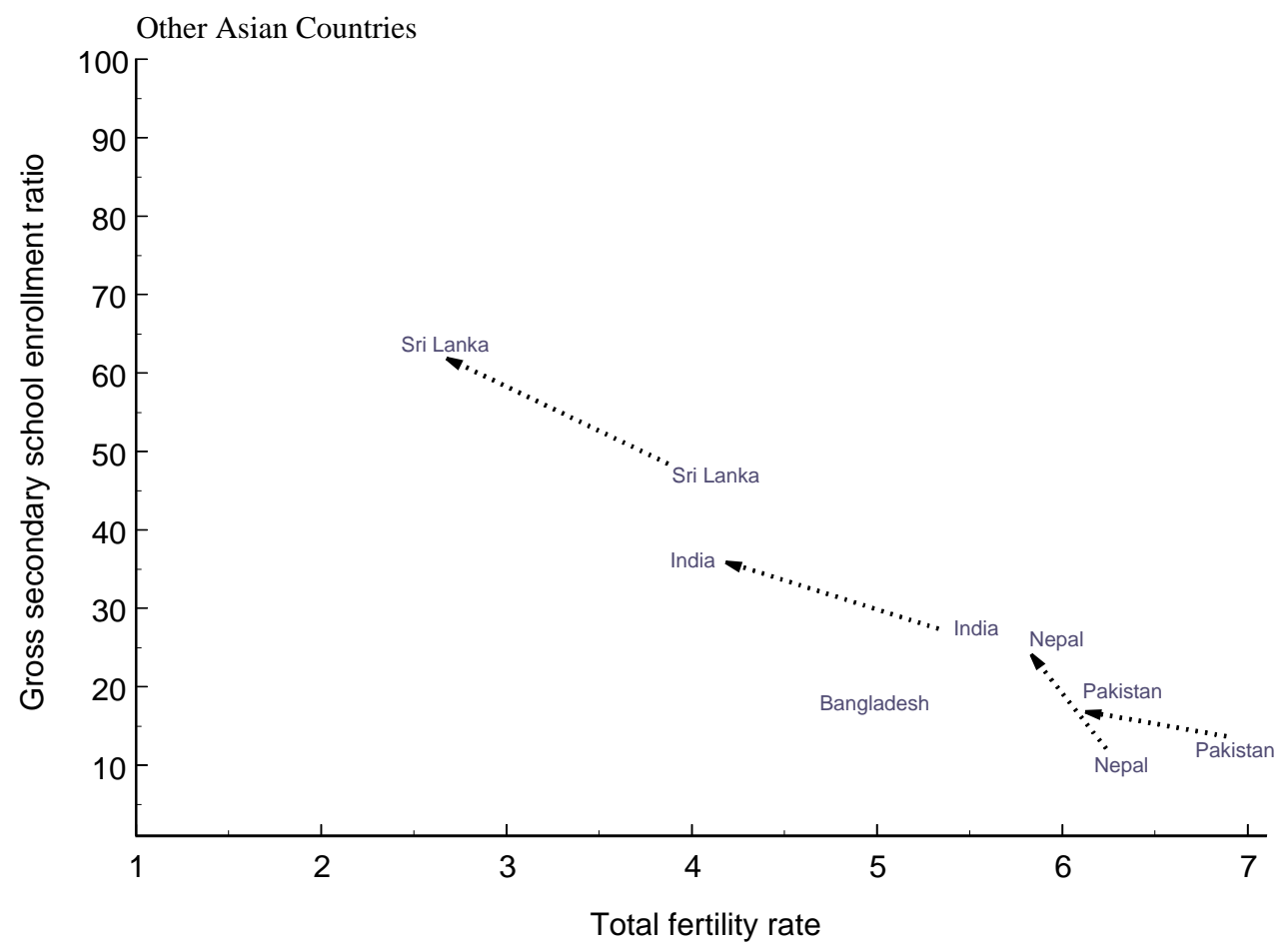

but its secondary enrollments showed little appreciable gain. India recorded progress in both the fertility and enrollment dimensions, and Sri Lanka evolved much as did its counterparts in East and Southeast Asia.

In what follows, we explore both the causes and the consequences of these developments. It is appropriate to begin by considering families and their decisionmaking, recognizing that families are set in environments whose parameters are established by markets and governments. The macroeconomic and policy climates are exogenous to families, but, as noted above, aggregated family-level decisions can shift the exogenous parameters.

Consider a newly married couple embarking on a reproductive career. Over the course of that career, the couple will make decisions about the number of children to bear and the education to be invested in each child. The time horizon 
for reproduction is limited by the reproductive span of the woman, but educational decisions will continue to be made after reproduction has ceased. At each age $t$, where we index age according to the age of the mother, the parents will consult an information set $I_{t}$ that summarizes their knowledge of the macroeconomy and, in particular, their perceptions and expectations of the economic returns to schooling. These rates of return affect parental decisions through the anticipation of transfers from grown children as well as through altruistic concern for the children's wellbeing. The information set also contains accumulated family-specific information on the educational abilities of the children, which may be combined with the aggregate returns to form child-specific forecasts.

At age $t$, having had $n_{t}$ children and having equipped them with amounts $\left(e_{i t}, i=1, \ldots, n_{t}\right)$ by way of education, the parents will decide whether to have another child (provided the woman is still capable of doing so) and whether to further the education of all, none, or a selected few of these children. Policy constraints may come into play with respect to education, such as when one child has scored too poorly on a primary-school leaving exam to proceed to academic secondary training.

This paper is not the place to discuss a fully dynamic model incorporating such features, but several points deserve emphasis. ${ }^{3}$ First, parents desiring to deepen human capital investments in children are unlikely to be able to finance the investments by borrowing against future income. They can restrict fertility in order to invest, but an alternative is to finance the investments from reductions in own consumption. Another alternative is to reduce both fertility and consumption. The school costs can also be met by transfers from grown children or the wider family. Our point is that although fertility reduction is a plausible outcome of the desire to capture the returns to education, it is not the only possible outcome.

The required degree of reduction will depend, in part, on the direct costs of schooling. These costs are sometimes dismissed as trivial, but can be important in low-income, rural settings when considered in relation to the scarcity of cash. 
In addition to the direct costs of schooling, parents may confront time costs in childrearing that are linked to schooling. Parents who themselves have had little or no schooling may not depart much from traditional modes of child care, but second-generation parents - those who have been further in school-may see a need to prepare their own children quite differently. We suspect that associated with the quantity-quality transition is a fundamental change in the nature of child care (LeVine et al. 1991), which may have reinforcing effects over the generations.

In the early stages of a quantity-quality transition, inequalities in investments among children are to be expected (Parish and Willis 1993), whether the result of ability-based differences in the returns to schooling or of sex preferences on the part of parents (Behrman 1988). Where such inequalities are tolerated, parents may feel little compulsion to divide educational resources equally among their children. A strategy of differential investment may let some parents escape the need to severely restrict fertility (or consumption) in order to finance schooling.

This discussion has presumed that the economic returns to schooling are known to parents, but the sources of such knowledge deserve comment. It is far from obvious that parental perceptions about returns are firmly grounded in empirical realities. More likely, knowledge of returns is based on impressions gleaned from social networks, peers, and the media. Very little research has considered the sources of these perceptions and their linkage, or the lack of it, to the macroeconomic data. ${ }^{4}$

\section{FERTILITY AND SCHOOLING: THE MACRO RECORD}

Armed with this micro-level perspective, we now briefly reexamine the Asian record on fertility and schooling. Here and later in the paper, we contrast the experiences of the rapidly growing economies of East and Southeast Asia 
with those of the slower-growing economies of South and South-Central Asia. As will become evident, these subregions present some sharp contrasts, but surprising similarities can also be found. The lessons that can be derived from the successful experiences of East and Southeast Asian countries cannot be thoroughly understood without reference to the wider regional context.

Figure 2 traces the record of fertility decline in Asia, with Figure 2a depicting the country-by-country data series in East and Southeast Asia, and Figure 2b doing so for the other Asian countries. In the East Asian context, the Philippines, Malaysia, and Indonesia now form a comparatively high-fertility group, with total fertility rates above 2.5 . The remaining countries of the subregion have reached or fallen below replacement-level fertility, with the declines for Korea,

Figure 2a Total Fertility Rates in East and Southeast Asia, 1950-95

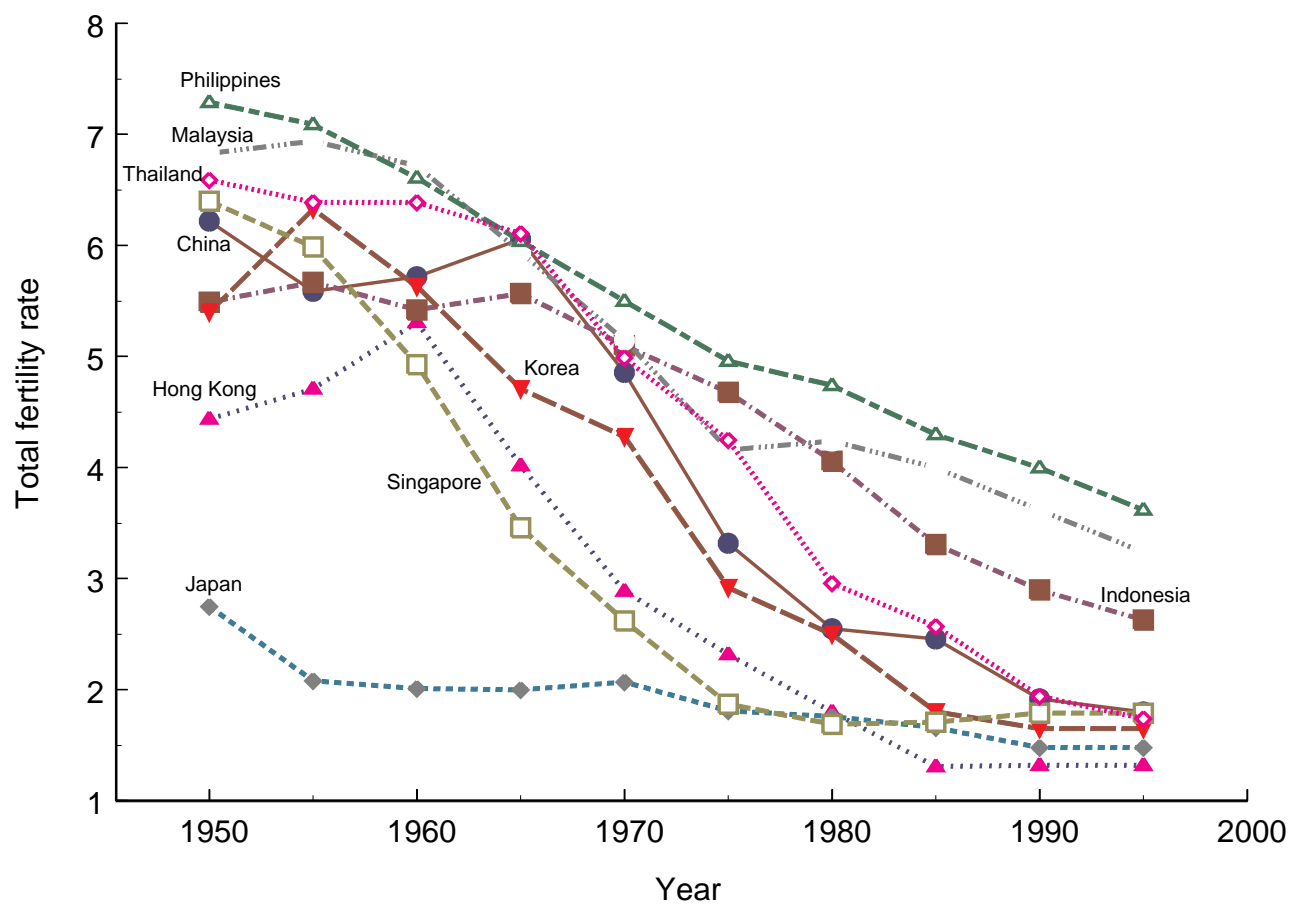


Figure 2b Total Fertility Rates in Other Asian Countries, 1950-95

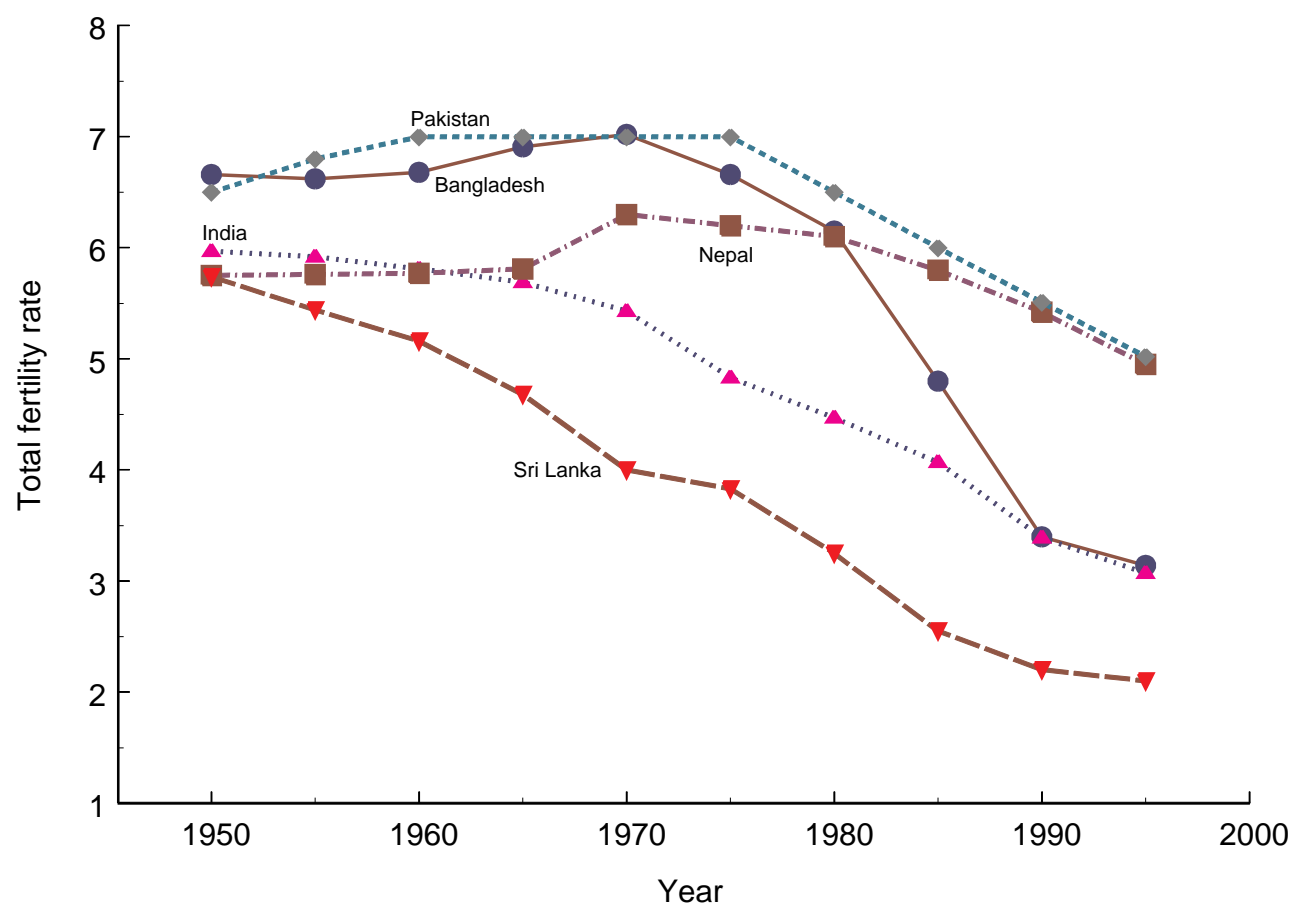

Thailand, and China preceded by declines of similar magnitude in Singapore and Hong Kong. As can be seen, Japanese fertility rates have long been near replacement. The other Asian countries (Figure 2b) have exhibited slower, shallower, or more delayed fertility declines, with the fertility fall in Bangladesh being a notable development of the 1980s. However, the differentials that once separated South from Southeast Asia are no longer so clearly evident. Indian fertility levels have come to match those of Indonesia, and Sri Lanka more closely resembles its East than its South Asian counterparts.

Accompanying fertility decline in the region has been an expansion of enrollments at all levels. ${ }^{5}$ In East and Southeast Asia (data not shown), gross primary enrollment ratios were very high throughout the period under consideration (1970-90), but elsewhere in Asia (see Figure 3), countries such as Sri Lanka, 
Figure 3 Primary Gross Enrollment Ratios, Other Asian Countries, 1970-90

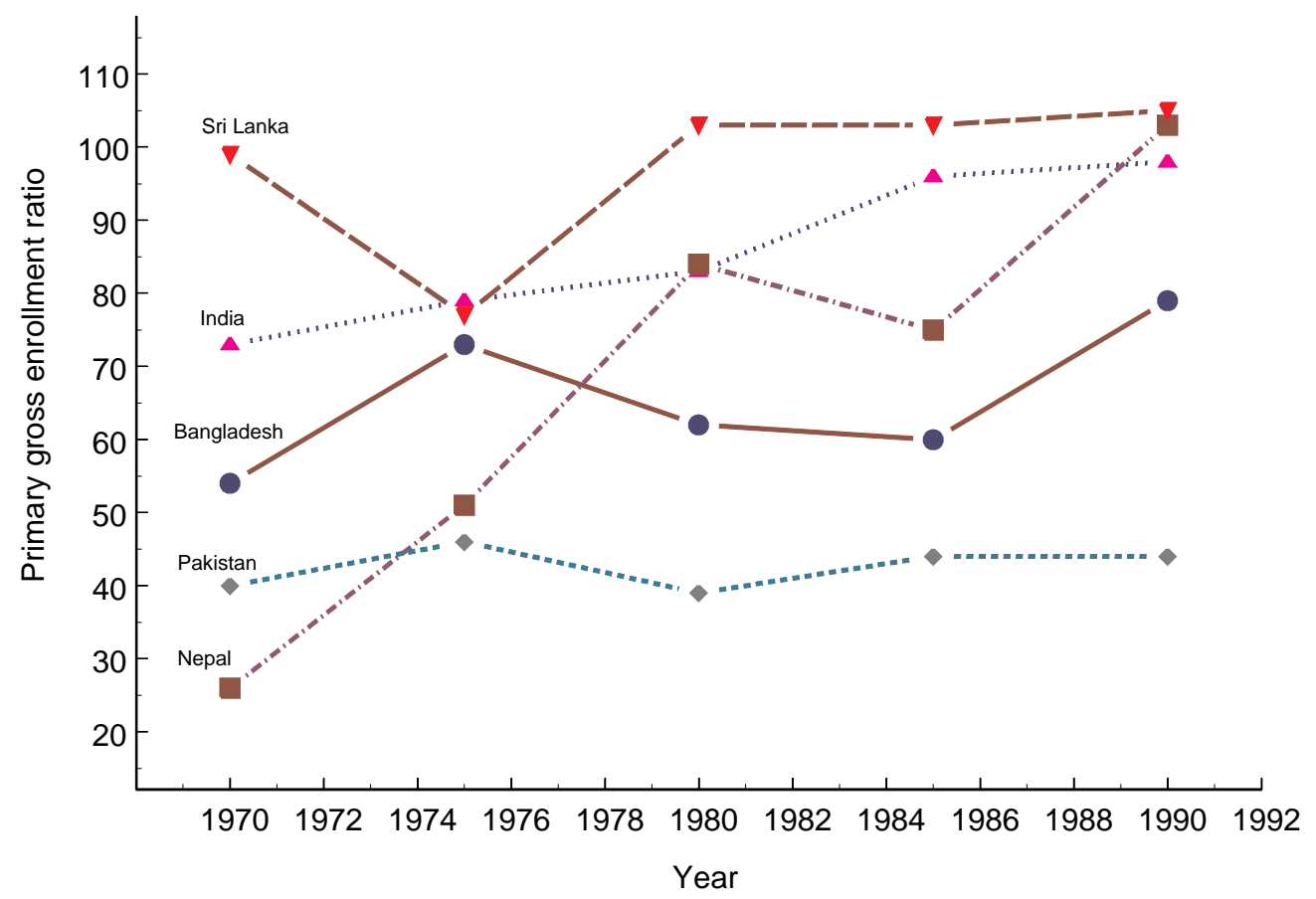

Nepal, and Bangladesh recorded significant gains at the primary level. Pakistan is all the more notable for its lack of progress.

At the secondary level (Figure 4), several East Asian countries have made rapid advances, with Korea being the clearest example. Apart from Thailand, whose gains at the secondary level were modest at best, steady improvement was the regional norm. In South and South-Central Asia, by contrast, progress was slower, with Sri Lanka again being the exception and surprising gains apparent in Nepal in spite of its poverty. Indeed, by the end of the period, Nepal had reached rough parity with Thailand in secondary enrollments.

Perhaps the single most important difference between the experiences of the East and Southeast Asian countries and those of the other Asian countries is the earlier achievement of near-universal primary schooling in the former group. 
Figure 4a Secondary Gross Enrollment Ratios, 1970-90

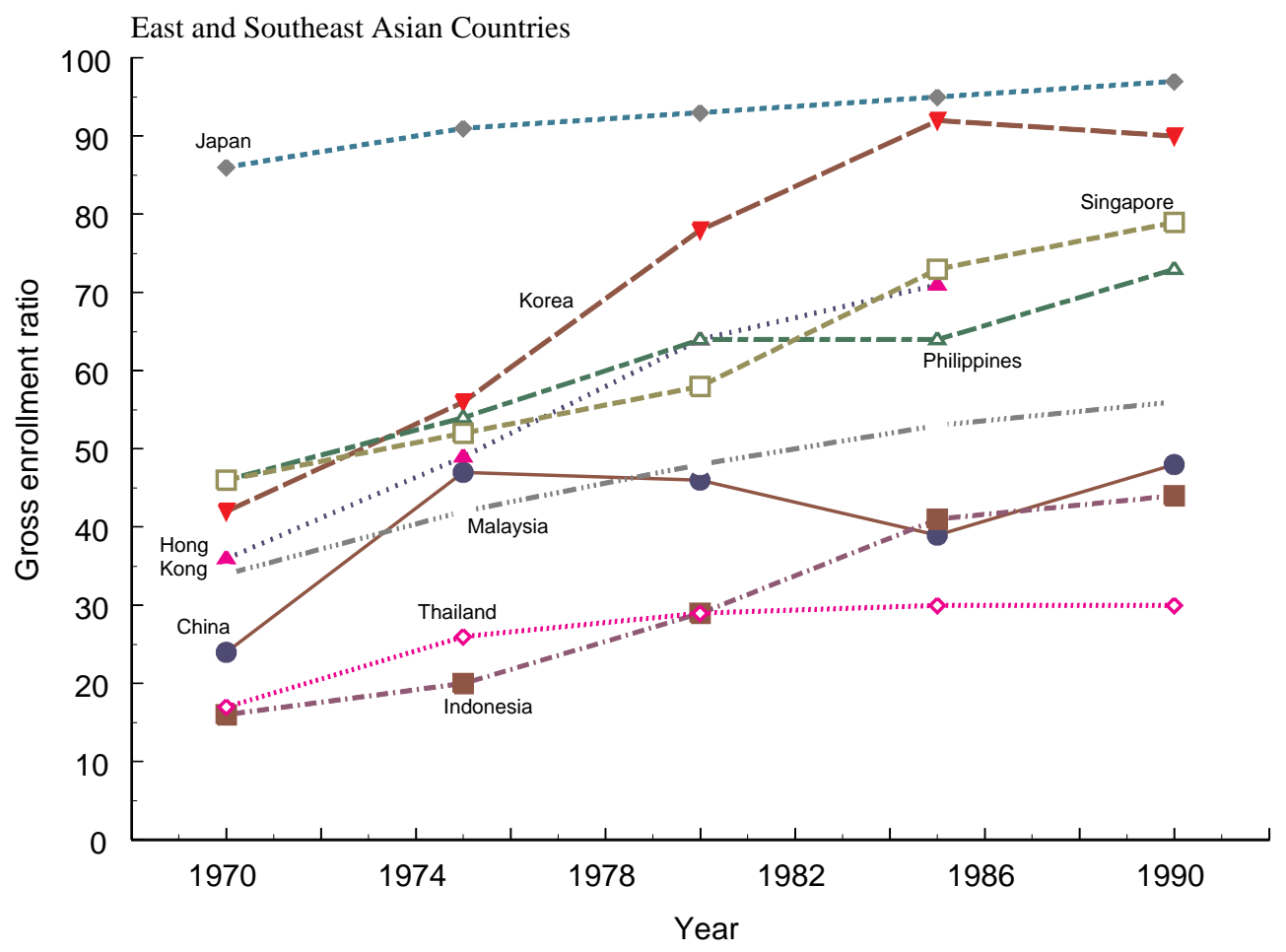

With the exception of Pakistan, the other Asian countries have made rapid progress in primary enrollments (Figure 3), but the initial advantages of the Asian "tigers" may have made the decisive difference to their rates of economic development.

According to Mingat (1998) and Mundle (1998), these successful countries realized and acted early on the need to expand primary and lower secondary education. Government subsidies clearly favored these levels of the educational system, and the private sector's involvement in education was encouraged (for the most part in tertiary schooling, although, in Indonesia, in primary as well). Moreover, highly selective promotion and admission policies (such as practiced in Latin America and Africa) were abolished, and the successful East Asian countries moved toward a system of automatic grade progression at the primary and 
Figure 4b Secondary Gross Enrollment Ratios, 1970-90

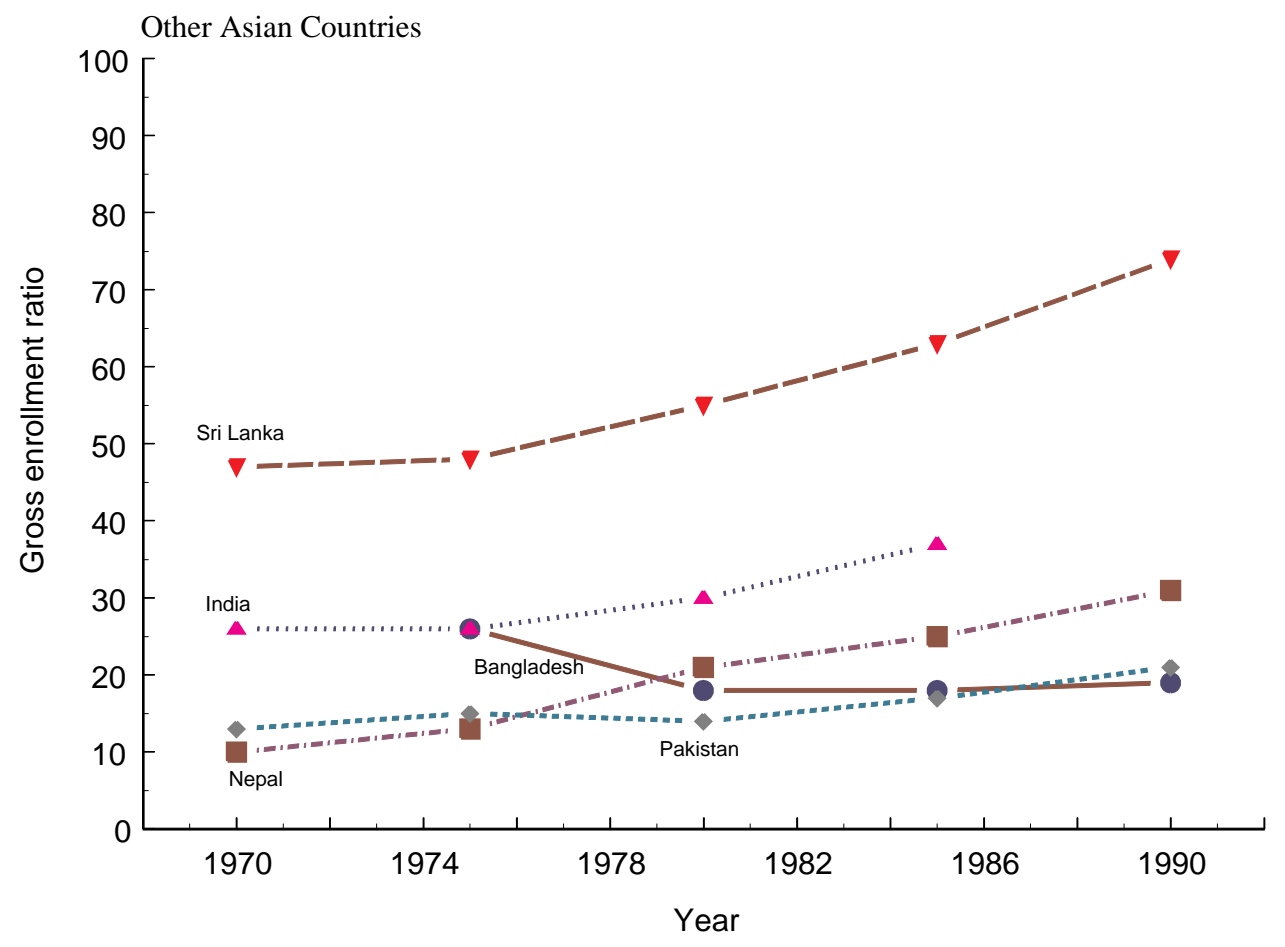

lower secondary levels. ${ }^{6}$ They also rapidly increased the number of schools in rural areas.

\section{RETURNS TO SCHOOLING}

In this section, we review empirical evidence on economic rates of return to schooling in Asia and then explore, with the aid of cross-national data, several hypotheses about the macroeconomic factors that can affect these returns. Rates of return are the fundamental building blocks of human capital theory (Willis 1986). They play the dominant role in determining demands for schooling, and thus have the potential to affect decisions about fertility as well. These returns are not fixed or exogenous quantities; rather, they are akin to prices and would 
thus be expected to vary with supply and demand conditions, a country's stage of development, and its exposure to world market forces (Stokey 1996). We emphasized at the outset the possibility of negative feedbacks, by which growth in the supply of educated labor could bring about a decline in rates of return. We must also consider positive feedbacks and external influences.

For developed countries, numerous studies have documented the rates of return to schooling and explored their determinants, most often through crosssectional studies but also, on occasion, using time series of cross-sections to examine temporal change. The possibilities for exploring time trends are more limited in developing countries, where differences in data collection and methodology make intertemporal comparisons difficult.

One important source of data for developing countries has yet to be fully exploited. In a series of publications, Psacharopoulos has assembled estimates of internal rates of return to schooling, the most recent of these being Psacharopoulos $(1985,1994)$. The data sources vary, but in most cases these estimates are based on earnings regressions from cross-sectional labor force surveys. The estimates compiled by Psacharopoulos include some from his own research, but most of the results are derived from studies by others. In screening such studies, Psacharopoulos has consistently excluded regressions with inappropriate controls (e.g., those including occupational dummies or other endogenous variables) and studies that assign forgone earnings to young children.

The estimates that meet these criteria can be criticized on other grounds. The internal rate-of-return method favored by Psacharopoulos requires assumptions about the number of years needed to progress from one level of schooling to the next. In many countries, time to completion of a given educational level is greatly affected by grade repetition, dropout, and reentry. With data lacking, applications of the method have also had to assume that the direct costs of schooling can be ignored. ${ }^{7}$ Despite the impressive effort to assure consistency, the labor force data and regressions vary in many aspects, including the nature of sam- 
pling, the inclusion or exclusion of women and those who do not work for wages, the treatment of unemployment, use of questionable explanatory variables, adjustments for urban-rural cost of living differentials, and so on. Furthermore, the reliance on cross-sectional data need not accord with the concept of expected returns over the longer run and does not permit cohort-specific technical change to be disentangled from other factors. Finally, labor force surveys do not allow either the quality of schooling or individual ability to be taken into account.

Nevertheless, few alternatives to the Psacharopoulos estimates present themselves. Some Asian countries are now in a position to supply repeated crosssectional labor force surveys (e.g., Korea and Taiwan), and as the number of these countries expands, this will provide a firmer foundation for the study of trends and differentials in rates of return. But for the moment, there are too few countries with such data to allow macroeconomic factors to be investigated. Although we recognize the limits of the Psacharopolous estimates, for our purposes these data will suffice.

\section{The empirical record}

Figures 5-7 provide the full set of Psacharopoulos estimates of returns to primary, secondary, and tertiary schooling for Asia. Where estimates are available for two or more points in time for a given country, we have linked the country observations with dotted lines to aid in the detection of trends. Few estimates are available for the rate of return to primary schooling, but there are a number of estimates to inspect at the secondary and tertiary levels.

These figures exhibit three main features. The first, and perhaps most important, is that the rate of return to schooling is quite high in absolute terms, almost irrespective of the level of schooling considered. The second noteworthy feature is the considerable variation in returns by country and time period. Interestingly, the East and Southeast Asian countries display neither consistently higher nor consistently lower rates of return. (Single-year estimates for Hong Kong and 
Figure 5 Private Rate of Return to Primary Schooling, 1965-89

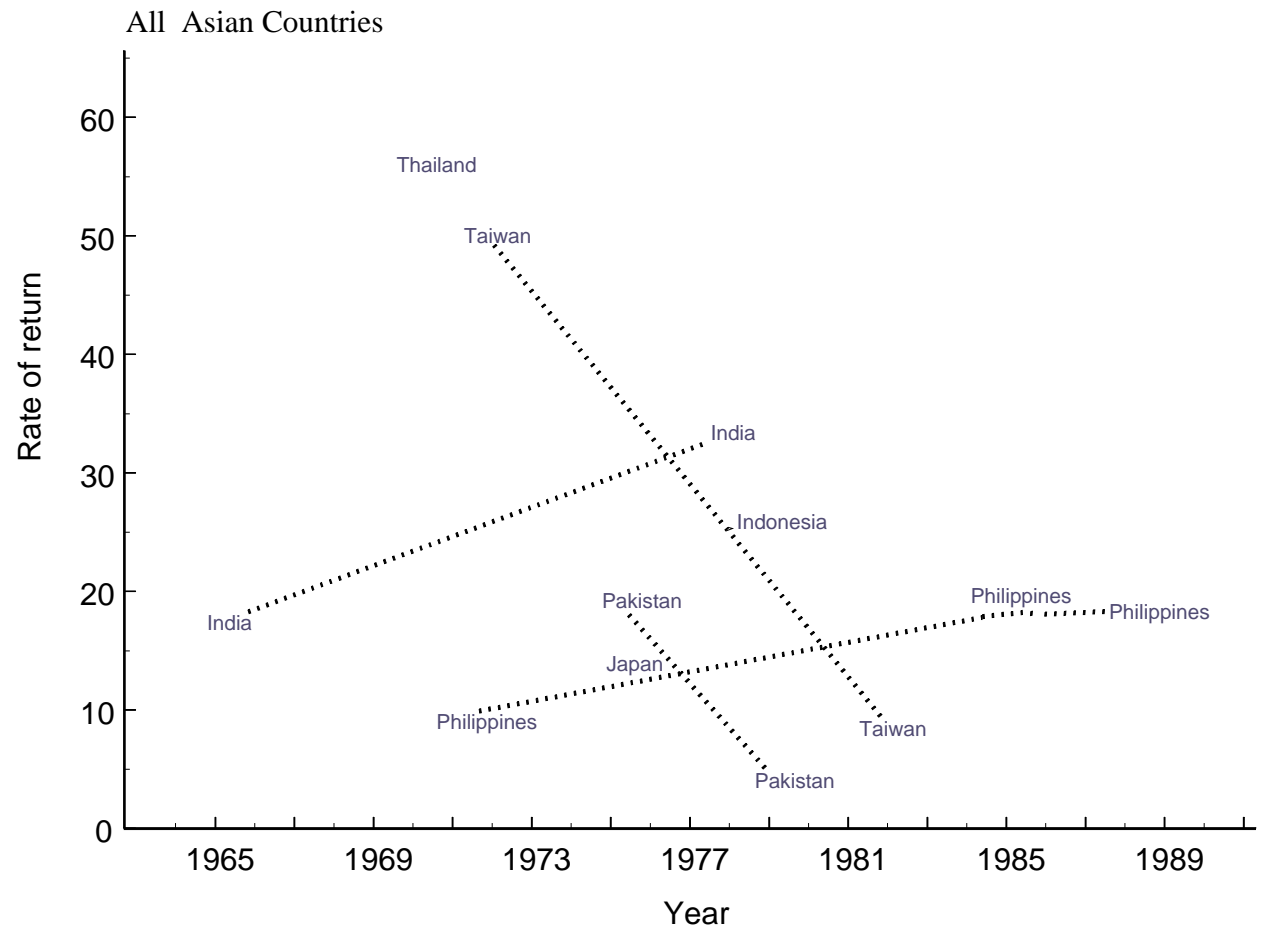

Singapore are high, as are the single-year estimates for Malaysia.) Third, time trends in the returns to schooling in Asia are difficult to discern. In the case of primary schooling (Figure 5), the few observations available permit no conclusion. At the secondary level (Figure 6), the picture is not much clearer. India exhibits little change in the rate of return; Korea presents evidence of a slight decline; estimates for Taiwan suggest (rather implausibly) a sharp drop in a two-year period around 1970; Indonesian returns rise and then fall from the mid-1970s to the mid-1980s; and similar behavior is evident for the Philippines. Estimates at the tertiary level (Figure 7) are also mixed and inconclusive in regard to trend.

For two countries with richer data series, Korea and Taiwan, additional evidence is available on wage ratios by level of education. (Wage ratios are not 
Figure 6 Private Rate of Return to Secondary Schooling, 1965-89

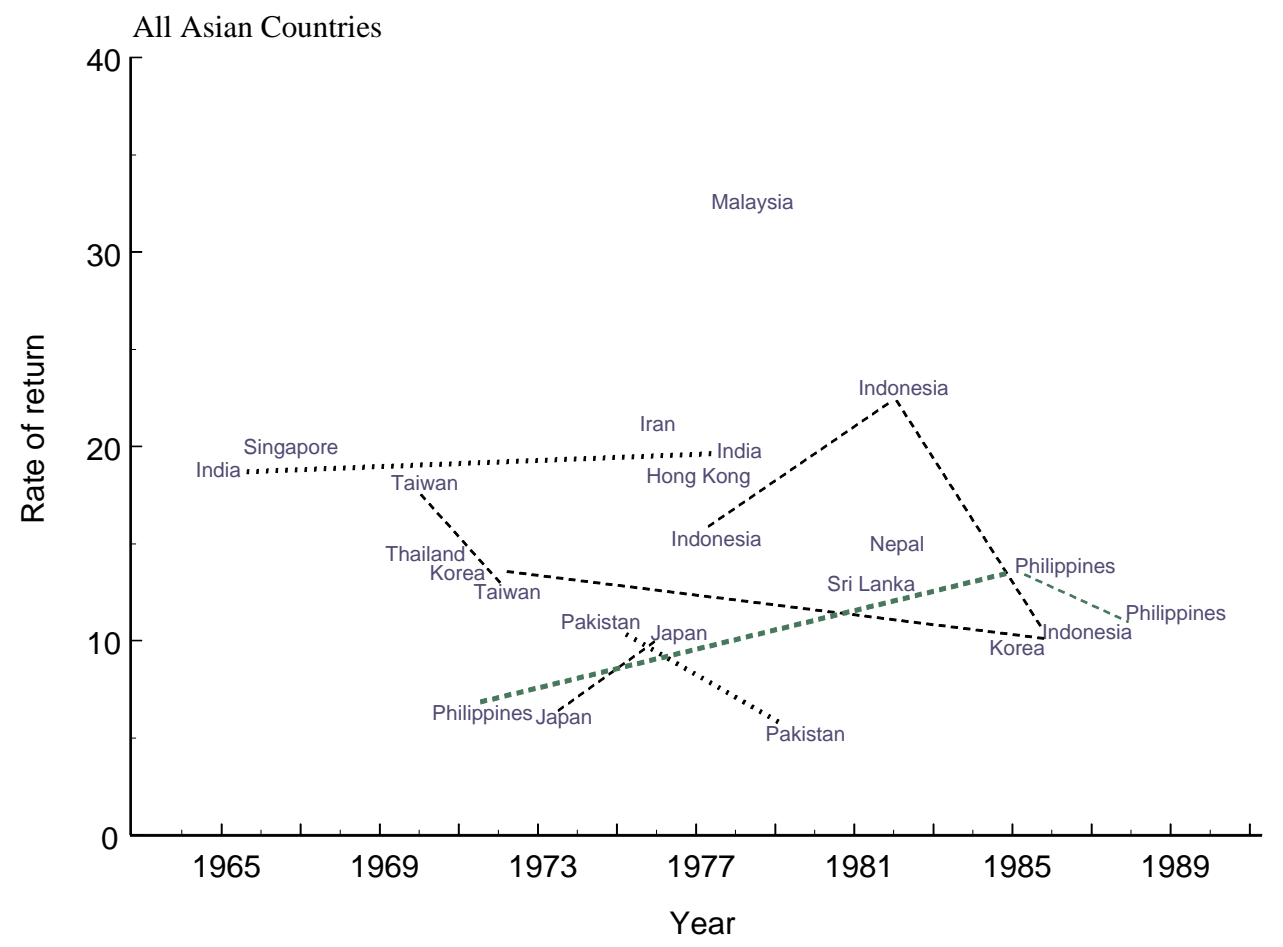

the same as internal rates of return, but one would expect similar trends in these alternative measures.) In the Korean case (Kim and Topel 1995), wages for university graduates rose relative to those for high school graduates until the mid1970s and then fell through the late 1980s. This pattern is also seen in studies of Korea by Davis (1992) and Park et al. (1996). In the case of Taiwan, Gindling et al. (1995) summarize the situation as one of relative stability from 1982 to 1991 in the returns to schooling. Yet, by the 1987-94 period, evidence was emerging of declining wage ratios (among those with junior college education and above relative to those with lower schooling) due to supply shifts, although the decline was masked by demand-side factors that had an opposite influence (Huang, 1997, 1998). ${ }^{8}$ 
Figure 7 Private Rate of Return to Tertiary Schooling, 1965-89

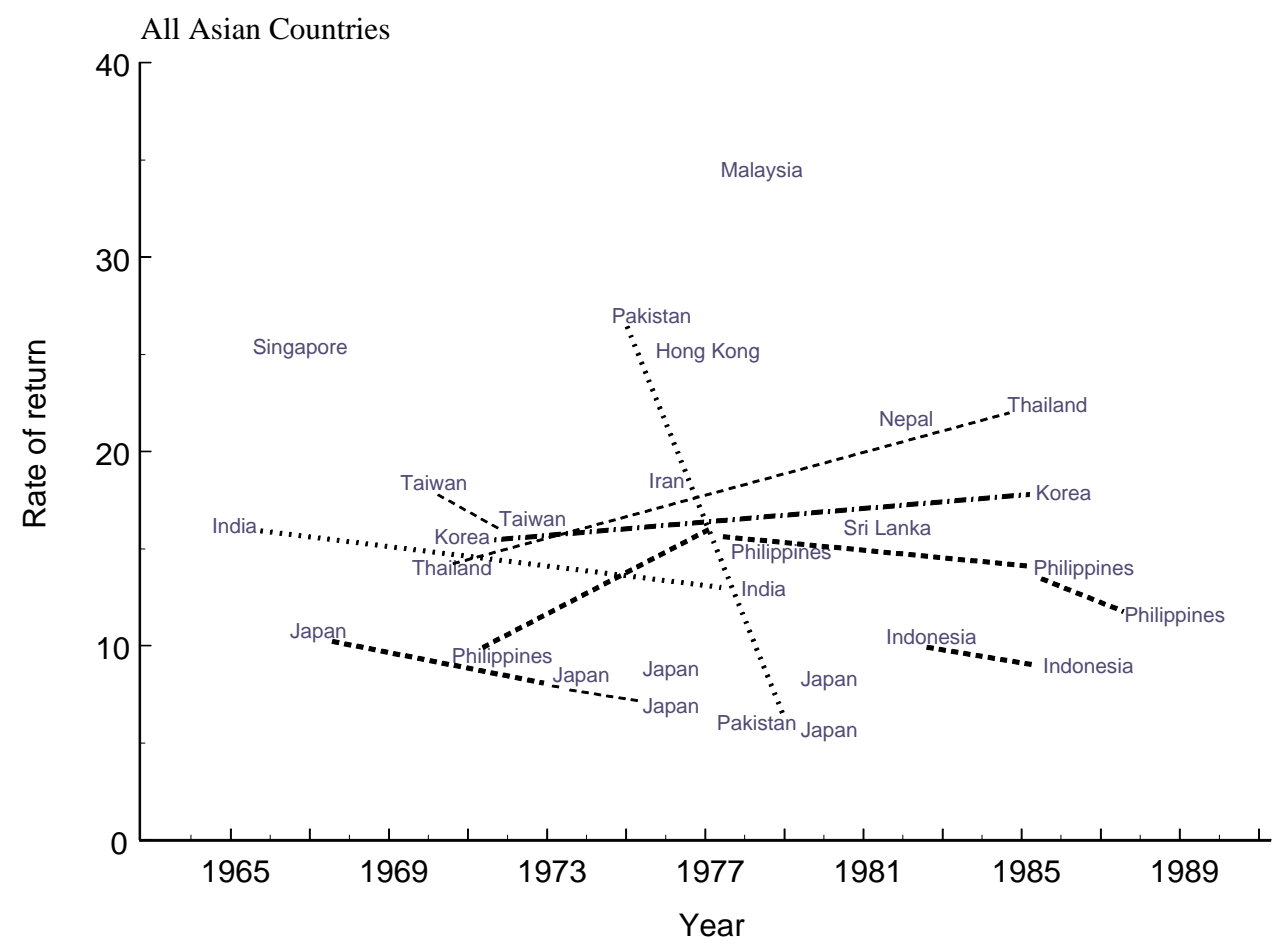

One reading of the Asian record, then, is that with the exception of Korea and, more recently, Taiwan, high economic returns to schooling have persisted. If these returns have been affected by macroeconomic forces, they have not been so strongly affected as to produce uniform or easily identifiable trends. One could even say, looking at the broadest features of the empirical record, that the returns to schooling have been remarkably stable, with the inevitable year-to-year and country-to-country variation dominated by the high mean level of returns. If stability in this sense is the correct characterization, then it is a striking feature of the Asian experience. Surely, in all Asian labor markets, the economic returns to schooling must reflect supply and demand (Fields 1994; Mazumdar 1993; Funkhouser 1998). How can the returns have remained largely unaffected? 


\section{Shifts in supply and demand}

On the supply side, there can be little doubt as to the magnitude of increase in better-educated Asian labor. The Barro-Lee estimates of the education of adults (Barro and Lee 1996) show substantial increases in average adult years of schooling. ${ }^{9}$ Examining another measure of skills, Berman et al. (1998) investigate trends in the proportion of non-production workers in manufacturing. Although in Indonesia the proportion remained about the same during the 1980s, it increased in South Korea, Pakistan, India, and Bangladesh.

To produce relative stability in returns to schooling, these supply shifts must have been counterbalanced by shifts in the demand for educated, skilled labor. Demand shifts are subtler and more difficult to detect than supply shifts, and there is considerable controversy about which demand-side influences have been dominant in Asia. We consider several leading hypotheses.

Capital accumulation. One possibility is that the accumulation of physical capital in Asia has encouraged a disproportionate shift in the demand for bettereducated labor. If capital and skilled labor are strong complements, such accumulation would tend to sustain the returns to schooling. As is well known, some Asian countries have compiled an impressive record of capital accumulation. Data on the non-residential capital to worker ratios (Summers and Heston 1991, data not shown here) reveal remarkable increases in Taiwan and Korea, although the series for Hong Kong, Thailand, and the Philippines exhibit lesser improvements.

But increases in physical capital, however remarkable in some cases, need not disproportionately stimulate the demand for skilled labor. On the key question of whether physical capital is complementary to skilled labor, there is little Asian research to cite. Hamermesh (1986) summarized much of the literature in an early and still influential review, which unfortunately included no developing countries. Although there was more variation in the estimates than might have been 
supposed, the tentative conclusion from this review was that capital and skilled labor are likely to be more complementary than are capital and unskilled labor. ${ }^{10}$

To our knowledge, no econometric research focusing on Asia has estimated the elasticities of substitution between physical capital, skilled labor, and unskilled labor. But trends in the composition of manufacturing from 1973 to 1988 suggest a role for capital-skill complementarities (World Bank 1993). In East Asian manufacturing, three subsectors are believed to have strong complementarities between capital and skilled labor-metal products, electronics, and machinery. These subsectors grew rapidly during 1973-88 in terms of their shares of total manufacturing value added. Taken together, their shares doubled in Japan and Singapore, nearly tripled in Indonesia and Korea, and quadrupled in Malaysia. To the degree that this growth was fueled by capital investment and associated with shifts in the demand for skilled labor, these subsectors may well have supported the returns to education. However, the textile and garment sectors, not usually viewed as having strong capital-skill complementarities, continued to account for an important share of manufacturing value added.

To sum up, the evidence in favor of capital-skill complementarities for Asia is weak and indirect. Nevertheless, in view of the region's impressive record of capital accumulation, this remains a persuasive hypothesis.

Technological change. An alternative explanation stresses the role of skillbiased technological change in sustaining the returns to schooling. This hypothesis has been advanced as the principal explanation for wage change in the United States (Johnson 1997; Berman et al. 1998; Berman 1994; Lawrence and Slaughter 1993).

Much evidence suggests that technology and skilled labor are complementary. The now-classic hypothesis is that education allows workers to use new technology more efficiently (Schultz 1975). Apart from studies of agriculture, much of the data favoring this hypothesis has been drawn from developed coun- 
tries, principally the United States. Examining a panel of U. S. manufacturing industries from 1960 to 1980, Bartel and Lichtenberg (1987) find that the implementation of new technologies was associated with an increase in the share of highly educated labor in total labor cost. Berndt et al. (1992) regress the nonproduction share of total employment on a capital-intensity measure and a measure of the share of high-technology capital in total capital. They find evidence of general capital-skill complementarity and complementarity of high-tech capital and skills. Other authors have emphasized the spread of computer technology (Autor et al. 1997; Berman et al. 1994), which may also be associated with skill upgrading and greater returns to skills. ${ }^{11}$

How relevant are such findings to Asia? In a study of educational wage differentials in Korea, Choi (1993) finds that workers in 1982 were paid more in industries undergoing rapid technological change, with technological change being measured by total factor productivity (TFP) growth rates from 1962 to 1976 . The spread of technology evidently benefited all workers in these industries. For men, the regression coefficient on the interaction between the TFP growth rate and schooling suggests that faster technological change raised the returns to education (particularly relative to low levels of schooling). Yet, somewhat contrary to expectations, Choi finds that for women the interaction between the TFP growth rate and high school education had a greater effect on wages than did the interaction with college education.

Choi also examines the effects of research and development (R\&D) spending within industries, focusing on R\&D from 1982 to 1988 as a determinant of wages in 1988. Increases in R\&D intensity in an industry (intensity being the ratio of R\&D expenditures to sales) were associated with higher wages for both men and women in that industry, but only for women did greater intensity bring about an increase in the educational wage differential at the secondary and tertiary levels. The interaction between R\&D intensity and college schooling was 
positive and significant for women, suggesting that although increases in intensity raised all women's wages, female college graduates benefited to a greater extent. Results such as these suggest a complex web of relationships linking technological change, returns to schooling, and gender.

Distinguishing technological change from capital accumulation. As Rodrik (1997) points out, fundamental identification problems confront any effort to partition growth rates into accumulation-related factors and technological change. Technological change is difficult to measure by any direct means. Its presence is usually inferred from the residuals in growth or wage share regressions, whose form is derived from more fundamental assumptions about production functions. The interpretation of residuals in terms of technological change rests, therefore, on arguable assumptions about the proper specification of the production function.

This leaves the terms of the debate unresolved. For the United States, Krusell et al. (1997) claim that they can explain much of the rise in wage differentials as the result of capital accumulation. Berman et al. (1998) insist that the differential is the result of pervasive skill-biased technological change. For Asia, Young (1995) argues that much of the East Asian productivity growth from 1960 to 1990 can be better explained by factor accumulation than by technological change. Kim and Lau (1994) also find that capital accumulation was the most important source of East Asian economic growth from the late 1950s until 1990. They see little evidence that the East Asian economies experienced appreciable technological progress during the postwar period, apart from the special case of Hong Kong. Yet Sarel (1997), examining many of the same countries, finds rapid rates of technological progress. In this debate, there is much contention over the details of modeling and the precise conceptualization of technological change. ${ }^{12}$

\section{How might trade affect returns?}

Did the outward trade orientation of the East and Southeast Asian economies affect their returns to schooling? Observers of East Asia's economic growth 
have often emphasized the region's adoption of export-promoting development policies. For example, Nancy Birdsall and Anne Krueger argue that export sectors in developing countries tend to be more labor intensive than import competing sectors, suggesting that the promotion of exports will increase employment and encourage a more equal distribution of income. ${ }^{13}$ The link to educational differentials in earnings, however, has been left unclear.

The theory on this question is inconclusive, because competing models of trade give different answers about how trade liberalization should affect wage differentials. According to the standard Heckscher-Ohlin and Stolper-Samuelson theories, when a labor-abundant country opens trade with a capital-abundant country, wages will rise and returns to capital will fall in the labor-abundant country. If East Asian countries are labor-abundant relative to the rest of the world, then, with trade, wages should rise in these countries. Alternatively, one can abstract from capital and other factors, and imagine that the two factors are skilled and unskilled labor (Robbins 1996; Wood 1995; Lawrence 1993; Katz 1992), with unskilled labor being the relatively abundant factor in Asia. In such cases, trade liberalization will likely cause the wages of unskilled labor to rise relative to the wages of skilled labor, and the returns to schooling should then fall.

Recent refinements of the Heckscher-Ohlin-Samuelson framework suggest additional implications. Davis (1996) and Leamer (1998) argue that what matters is not global but rather local factor intensity. For example, Taiwan may have an abundance of unskilled labor in relation to the world, but when compared to the Philippines or Thailand, Taiwan may be relatively abundant in skilled labor. Therefore, when Taiwan opens trade with its neighbors, its returns to skilled labor could rise. Leamer notes a further complication: a country's comparative advantage can shift as a result of physical capital accumulation and increased educational levels of its workers. Through mechanisms such as these, the effects of trade on wages could well change over time. Taiwan is often cited as a country where this has occurred (Ranis 1996). 
Apart from effects attributable to comparative advantage and factor prices, trade may also play an important indirect role by spurring capital accumulation. A country's success in exporting may encourage foreign direct investment on the part of multinationals, because export orientation signals that the macroeconomy is being well managed. If capital accumulation is faster as a result of foreign direct investment, and if capital is complementary with schooling, the returns to schooling could then rise. Stokey (1996) has traced the dynamic implications of such links. Her simulation model incorporates three factors-capital, unskilled labor, and skilled labor. Skilled labor and capital are taken to be complements. In the context of this model, trade liberalization by a representative developing country encourages the inflow of capital from developed countries. The increase in capital raises the returns to skilled labor over the medium run. Households, noting the increase in these returns, respond by increasing their investments in human capital. Over the long run, the ensuing supply shift then bids down the returns to skilled labor. The return to skill thus increases with the opening of trade but subsequently decreases as educational levels rise.

The trade-technology link. We mentioned above the difficulty of separating technological change from capital accumulation; it is equally difficult to distinguish the direct role of trade from its role as a conduit for technological change. If trade is associated with technology transfer, and if technology and skills are complementary, then this, too, could be a mechanism that supports the returns to schooling.

According to Pack and Page (1994), by exporting, countries can obtain recent, "best practice" technology. For example, its substantial export earnings have allowed Taiwan to import the latest equipment. Pack and Page estimate that a considerable fraction of the residual in productivity growth could be attributed to the technology embodied in imported equipment. In addition, exporting can encourage direct technology transfer from developed-country buyers to their suppliers as the former strive to ensure quality control. Korea and Taiwan are be- 
lieved to have obtained technology in their footwear and clothing industries from international buyers. As Keller (1997) notes, trade also allows countries to obtain $R \& D$ cheaply through another route. The results of $R \& D$ are evident in blueprints, which can then be reverse-engineered. Whatever the mechanism, Nelson and Pack (1998) stress that technology adoption is not a passive process, but requires active engagement in learning-by-doing. Such learning is facilitated by an educated labor force that is stocked with managers, engineers, and applied scientists.

Although the means of technology transfer remain difficult to identify, a growing empirical literature examines whether countries benefit from the R\&D investments made by their trading partners. Much of the evidence is drawn from developed countries, ${ }^{14}$ but a few studies have examined developing countries. Two of these find evidence that East Asian economies have benefited from the R\&D investments of their trading partners. Choi (1993) investigates the spillover benefits for Korea of changing R\&D intensity within OECD countries. The OECD R\&D intensities have a positive effect on Korean workers' wages, although only for Korean women does the educational wage differential increase. Indeed, for men this mechanism seems to compress wage differentials.

Further evidence, albeit indirect, is provided by Evenson and Singh (1997), who examine 11 Asian countries over the period 1970-93. They find that the beneficial effects of international investments in $R \& D$ were greater in Southeast Asian countries than in South Asian countries. (Evenson and Singh focus not on earnings differentials as such, but rather on productivity effects as measured in gross domestic product.) In their regressions, countries that had a higher share of imports relative to GDP benefited more from foreign R\&D than did countries with low levels of imports. Evenson and Singh argue that a developing country needs a minimum level of human capital in order to take advantage of foreign $\mathrm{R} \& \mathrm{D}$. At least for the high-performing Asian countries in their sample, a positive 
productivity gain resulted from the interaction of foreign $\mathrm{R} \& \mathrm{D}$ and domestic secondary school enrollments.

Only a few researchers have attempted to directly connect changes in relative wages in developing countries to changes in their trade policies. Robbins (1994), examining the effects of trade liberalization in Chile, finds that relative wages of university graduates compared to primary school graduates increased during the 1980s, and that relative demand shifts favored skilled workers over unskilled workers. He cannot, however, tie these shifts in demand to trade policy changes. In another paper, Robbins (1996) uncovers similar effects of trade liberalization in Colombia, Costa Rica, and Uruguay, attributable mainly to the expansion of sectors that intensively use skilled labor. ${ }^{15}$ Although the connection remains plausible, the literature has yet to establish a convincing link between changes in trade policy and changes in wage differentials.

\section{Cross-country evidence}

To summarize this wide-ranging discussion, we present in Table 1 a set of descriptive, cross-country regression models in which the dependent variables are the rates of return to schooling at the primary, secondary, and tertiary levels. The regression models are estimated separately by level of education. There are very few observations on primary rates of return, and these findings can only be taken as suggestive.

The explanatory factors entering these models include the value of nonresidential capital per worker, ${ }^{16}$ the ratio of adults over 25 years of age with the specified level of education to those with the next lower level of educational attainment, ${ }^{17}$ a measure of openness to trade, ${ }^{18}$ regional dummy variables, and dummy variables for time period. The specification we employ is loosely modeled on the constant elasticity of substitution (CES) production function specifications often used in the labor literature (for instance Freeman 1979). 
We would expect the capital per worker variable to have a positive influence on returns to both secondary and tertiary education. The adult educational ratios should have a negative effect, because these are measures of the relative supply of skills in the labor market. According to the discussion above, openness to trade should be associated with the transfer of skill-intensive technology, among other things, and might have a positive effect on the returns to schooling at the secondary or tertiary levels.

In Table 1, we first present the results of a model containing only the regional dummy variables and time period dummies. The omitted regional category is "developed countries," although Japan is classified under East and Southeast Asia. Two features of the benchmark regressions are noteworthy. First, there is little here to suggest that returns to schooling are much different in East and Southeast Asia than in developed countries, whereas rates of return in Africa and Latin America (at least at the secondary and tertiary levels) are clearly higher. Second, only weak evidence emerges of time trends in returns at the primary or tertiary levels, although evidence of downward trends is somewhat stronger at the secondary level.

In the second column of the table, we include measures of non-residential capital per worker and the ratio of adults by educational level. The third column adds a trade openness measure, defined as the ratio of imports plus exports to gross domestic product. Contrary to expectations, neither capital per worker nor the adult educational ratio makes much of a difference. Capital per worker is negatively associated with educational returns at all levels of schooling, although significant only at the tertiary level. More consistent with theory is the negative sign of the educational ratio coefficients for primary and tertiary returns - as would be expected from shifts in the relative supplies of labor-but these estimates are also insignificant. The lack of significance is surprising given the Korean results (Kim and Topel 1995) and similar findings from other countries with cross-section, time-series data. ${ }^{19}$ 
Table 1 Rate of Return Regressions: Full Method Estimates from Psacharopoulos $(1985,1994)$

Returns to Completed Primary

Constant

( |z|-statistic)

Africa

Latin America

East and Southeast Asia

Other Asia

Ratio of completed primary to none or incomplete

Non-residential capital per worker (000's)

Trade openness

1970-1979

1980 and later

$R^{2}$

Number of observations

Constant

( $|z|$-statistic)

Africa

Latin America

East and Southeast Asia

Other Asia

Ratio of completed secondary to primary or incomplete

Non-residential capital per worker (000's)

Trade openness

1970-1979

1980 and later

$R^{2}$

Number of observations
19.920

(1.69)

23.136

(1.98)

9.035

(0.81)

7.713

(0.64)

.430

(0.03)

$-2.233$

(0.23)

$-3.700$

(0.43)

.124

54

Returns to Completed Secondary

15.192

14.622

(5.26)

5.126

(2.19)

4.206

(1.57)

3.677

(1.07)

$-5.013$

(2.12)

$-4.769$

(1.91)

.247

109
24.686

(1.43)

16.483

(0.84)

3.287

(0.20)

4.356

(0.29)

1.290

(0.06)

$-1.623$

(0.13)

$-.434$

(0.50)

1.113

(0.05)

$-1.209$

(0.06)

$-3.911$

(0.21)

$-7.141$

(0.44)

9.741

(0.44)

$-6.341$

(0.53)

$-.311$

(0.37)

.364

(2.11)

22.227

(1.11)

11.265

(0.52)

.092

.273

33
12.206

(3.96)

$\begin{array}{r}(3.46) \\ \hline\end{array}$

25.848

28.113

(5.85)

(5.68)

2.387

(0.82)

5.334

(1.51)

$-.426$

.092

(0.13)

(0.03)

3.904

5.130

(0.93)

(1.22)

2.390

6.483

(0.39)

(1.03)

$-.052$

$-.034$

(0.36)

$(0.25)$

.063

(1.81)

$-5.007$

(1.72)

$-7.781$

(2.16)

.453

.510

71 
Table 1 (continued)

\begin{tabular}{lrrr}
\hline & & \multicolumn{2}{r}{ Returns to Tertiary } \\
Constant & 13.506 & 19.960 & 17.046 \\
( |z|-statistic) & $(8.43)$ & $(6.07)$ & $(4.42)$ \\
Africa & 17.406 & 11.710 & 11.726 \\
& $(7.28)$ & $(2.92)$ & $(2.54)$ \\
Latin America & 8.514 & 4.848 & 6.164 \\
& $(4.23)$ & $(1.87)$ & $(1.84)$ \\
East and Southeast Asia & 3.992 & -1.491 & -1.422 \\
& $(1.92)$ & $(0.60)$ & $(0.52)$ \\
Other Asia & 6.079 & -.332 & .806 \\
& $(1.97)$ & $(0.08)$ & $(0.19)$ \\
Ratio of tertiary & & -3.759 & -2.740 \\
to secondary & & $(1.53)$ & $(1.00)$ \\
Non-residential capital & & -.255 & -.231 \\
per worker (000's) & & $(2.24)$ & $(1.89)$ \\
Trade openness & & & .046 \\
& & & $(1.32)$ \\
1970-1979 & & & .428 \\
& & & $(0.16)$ \\
1980 and later & -2.426 & & -1.838 \\
& $(1.29)$ & & .353 \\
$R^{2}$ & -4.197 & & 77 \\
Number of observations & $(2.05)$ & .331 & 77 \\
\hline Omitted region: & .353 & 115 & \\
\hline
\end{tabular}

Omitted region: developed. No observations from Middle East or from developing-country Oceania. Japan in East and Southeast Asia.

In the full specification presented in column 3, only the trade openness measure is positively associated with returns to schooling. It is a (weakly) significant influence on both primary and secondary returns, although insignificant in the tertiary returns regression. Finally, the time period dummy variables, which in the full specification of column 3 can be viewed as proxies for skill-related technological progress, are significant only in the secondary schooling regression. As in the benchmark regression of column 1 , in the full model they suggest a downward trend in the returns to secondary schooling. ${ }^{20}$

These results provide weak support for the proposition that trade affects the returns to schooling, to judge from the coefficients in the primary and secondary 
returns regressions. Perhaps the coefficients reveal the aspect of trade associated with comparative advantage and tendencies toward factor price equalization. Had trade been an important conduit for new technology, then one would have expected the openness to trade measures to be more clearly associated with the returns to tertiary schooling. However, the industry-level findings of Choi (1993) for Korea seem to suggest that technological progress could have a greater effect on returns to secondary schooling than on tertiary returns.

These cross-national regression estimates should be regarded cautiously, because such data do not provide a firm foundation for understanding the complementarity of capital and skills or the precise roles of trade and technology. No doubt country fixed effects are important in determining the returns to schooling, as are specific aspects of labor market policies and schooling policies that affect, respectively, wage levels and degrees of access to secondary and higher levels of schooling. Even in the absence of country-level panel data, however, one would have anticipated clearer evidence in the cross-country record of the influence of skills accumulation, growth of capital per worker, and technological change, which must be among the fundamental forces shaping the returns to schooling.

\section{QUANTITY AND QUALITY AT THE FAMILY LEVEL}

From an Asian family's perspective, the workings of the macroeconomy are doubtless hidden from view or are only dimly perceived. As we argued at the outset, little is known about how families themselves gauge the returns to schooling, and it is possible that local rather than national labor markets exert a disproportionate influence on their thinking. Even if the national labor markets are salient, family perceptions of returns could significantly differ from, or lag well behind, the national-level empirical realities. Socially pertinent information about economic change would tend to filter slowly through a family's networks of peers 
and relatives, and although the media would transmit information more rapidly, it is not clear that their inevitable focus on novelty and crisis would supply families with information bearing on longer-run concerns.

Given the limited and fragmentary information that families possess, it is sensible to conceive of their schooling and fertility decisions as being based only on the broadest features of the returns to schooling. The dominant empirical regularity identified in the previous section is that returns to schooling are higheven very high-in absolute terms. Perhaps it is sufficient that Asian families appreciate this central fact; perhaps, in most circumstances, variations in returns about the high mean are of second-order importance.

If they take the high returns to schooling as a given, families are then likely to be more concerned with the direct costs of schooling, the time costs entailed in properly preparing their children for schooling, and the examination-based and other policy barriers that might prevent them from securing access to these high returns. In following this line of thinking, we are led to consider evidence of quantity-quality tradeoffs at the level of family decisionmaking.

In this section, we explore a range of micro-level data sets that contain information on fertility and child-by-child schooling investments. We examine data from Pakistan (1991), Bangladesh (1993), Indonesia (1993), Malaysia (1988), the Philippines (1993), Thailand (1987), and Taiwan (1989). The aim is to estimate reduced-form models of fertility and children's schooling that may elucidate the factors that can produce a quantity-quality tradeoff. We adopt specifications that, although not identical across countries, are sufficiently similar to permit comparison of effects.

The data sets form a diverse group. For Pakistan, we employ the 1991 Living Standards Measurement Survey (LSMS), a nationally representative data set containing substantial information on both fertility and children's schooling. For Bangladesh, we use data from a rural population that has been under demo- 
graphic surveillance since 1982 by the Extension Project (EP), a study similar in design to the better-known Matlab project. The data for Indonesia and Malaysia are drawn from the Family Life Surveys (FLS) conducted by RAND and its country collaborators. Demographic and Health Surveys (DHS) data are available for the Philippines and Thailand; and for Taiwan, we use the Taiwan Women and Family Survey (TWFS) described in Parish and Willis (1993).

To the degree possible, we have assembled data on the fertility of the respondent (the woman) in each household and on the education of all of her own children. Our fertility measure is children ever born, which is available in all the data sources we use. A key concern across the surveys, however, is the measurement of children's education. Typically, less is known about the education of children who no longer reside in the household than about the schooling of those who are still resident. For example, current school attendance is not usually ascertained for non-resident children, and often the levels of schooling attained are summarized in broader groupings than for resident children.

In our data sets, the designs of the Pakistan LSMS, the Malaysian and Indonesian FLS, the Thailand DHS, and the Taiwan TWFS all permit useful information on schooling to be retrieved for non-resident children. The Philippines DHS data on schooling are limited to resident children, as are the Bangladesh Extension Project data. Elsewhere we have studied the likely selection bias for the Philippines (Montgomery et al. 1998b) and have concluded that if only children aged 18 and younger are considered, the biases are likely to be small. In the case of Bangladesh, levels of schooling are low enough that serious bias is also unlikely.

\section{Specification}

In modeling fertility and children's school attainment, we use ordered-probit models for each. This is a sufficiently flexible approach to capture the main features of lifetime fertility and educational attainment. Since many of the women 
interviewed are in the midst of their reproductive careers, and likewise many of the children have not completed their schooling, we must employ controls for the woman's age and her children's ages.

To understand the specification from the perspective of the quantity-quality tradeoff, recall that models being estimated are reduced-form in nature. A tradeoff is therefore evident if a given exogenous variable has the effect of reducing fertility and raising children's educational attainment. This sign pattern does not in itself reveal the mechanism by which the tradeoff emerges, but rather signals the existence of such a tradeoff.

In our discussion, we focus on a small set of such explanatory covariates. The woman's own educational attainment enters each model, as does the education of her spouse if she is married (otherwise the spouse's variables are set to zero). Urban residence is included, although this is current residence. A collection of indicators of the household's economic status is also included. These heterogeneous measures range from indices of household possessions (Pakistan, Bangladesh, Malaysia, the Philippines, Thailand) to indicators of the occupation of the spouse (Taiwan). As discussed elsewhere (Montgomery et al. 1997b), such indices are likely to be weak but still useful proxies for the preferred measures of permanent (or longer-term) income.

For three countries — Pakistan, Indonesia, and Malaysia — we can introduce time-specific controls for the presence of schools in the community. We use the dates on which the schools were established to construct measures of access to schools as of the year in which the woman in question reached age 17. The idea is to characterize this aspect of the decision environment as it existed around the time of her marriage.

Given the data available, identification of trends is difficult. We include measures of the birth cohort of the mother, recognizing that such measures must be associated with the mother's age and thus with the degree to which her fertil- 
ity career is complete (and, less directly, with the completeness of her children's education). For Taiwan, we have access to information on fertility and education in the previous generation, as measured by the number of the respondent's siblings and their education. As did Parish and Willis (1993), we use these data to shed light on earlier regimes of fertility and educational decisionmaking.

\section{Results}

We do not dwell on country-by-country details of the estimates, but rather describe the common features of the results. The models themselves are presented in Tables 2 through 9.

Woman's education. A striking result is that better-educated women have lower lifetime fertility and equip their children with greater education. This finding is consistent across countries and data sets, with the curious exception of Indonesia, where fertility is not significantly reduced except by senior secondary or higher schooling. The effects of the woman's education on her fertility range from modest to powerful (results not shown) and the effects on the level or years of children's education are also substantively important. As we seek to understand the quantity-quality tradeoff at the family level, therefore, this variable merits prime consideration.

Spouse's schooling. The schooling of the spouse tends to reduce fertility, although it is generally of less importance than the woman's schooling. Taiwan and the Philippines present exceptions to the rule, with the spouse's schooling having a positive influence on fertility. This may be evidence of an income effect not captured by other controls. Where children's education is concerned, the spouse's schooling usually exerts a significant positive influence, although the magnitude of the effect tends to be smaller than for the woman's schooling. ${ }^{21}$ In summary, increases in the schooling of men tend to induce a quantity-quality tradeoff. 
Table 2 Children Ever Born and Level of Schooling: Pakistan LSMS, 1991

Children Ever Born

$\mathrm{N}=3,296$
Children's Level of Schooling $\mathrm{N}=9,177$

Child's Sex

Girl

( |z|-statistic)

Woman's Schooling

Primary

$-.302$

(4.54)

$-.656$

(9.66)

Spouse's Schooling

Primary

$-.024$

(0.49)

$-.079$

(1.61)

$-.300$

(4.03)

Household Possessions

Index

.104

(2.11)

$-.012$

(1.55)

Residence

Urban

.117

Woman's Cohort

Born before 1950
$(0.30)$

Children's education levels: none, primary, middle, secondary, college and higher. Coefficients not shown: mother's age and powers of age, child's age and powers of age, school availability, ordered-probit cut points.

Urban residence. In view of the easier access to family planning services and schools in urban areas, and the profound changes underway in the distribution of population between rural and urban areas, the role of urban residence in promoting a tradeoff is of considerable interest. Our results indicate that urban 
Table 3 Children Ever Born and Years of Schooling: Bangladesh Extension Project, 1993

Children Ever Born

$\mathrm{N}=9,782$

Child's Sex

Girl

( |z|-statistic)

Woman's Schooling

Incomplete primary

Complete primary or more

Spouse's Schooling

Incomplete primary

Complete primary or more

Household Possessions

Radio

Electricity

House size medium

House size large

Woman's Cohort

Born before 1950

Born 1950-1955
Children's Years

of Schooling $\mathrm{N}=19,779$

$-.058$

(1.96)

$-.191$

(5.70)

(0.98)

$-.117$

(3.91)

$-.105$

(4.41)

$-.040$

(1.28)

(1.27)

Coefficients not shown: mother's age and powers of age, child's age and powers of age, regional dummies, ordered-probit cut points.

residence is usually an important positive influence on children's educational attainment (the Philippines is an exception) and, depending on country, generally exerts a modest negative influence on fertility.

Economic status. Because the data sets are heterogenous in measures of economic status, we cannot draw detailed conclusions from these coefficients. 
Table 4 Children Ever Born and Level of Schooling: Indonesian Family Life Survey, 1993

Children Ever Born

$\mathrm{N}=3,578$

Child's Sex

Girl

( |z|-statistic)

Woman's Schooling

Primary

.215

(0.99)

$-.013$

$(0.04)$

Senior Secondary or higher

$-.647$

(2.03)

Spouse's Schooling

Primary

$-.308$

(1.39)

Junior Secondary

$-.339$

(1.14)

$-.101$

(0.31)

Residence

Urban

$-.044$

Woman's Cohort

Born before 1950

(0.72)

.004

(0.05)
Children's Level of Schooling $\mathrm{N}=8,602$

.562

(7.07)

1.148

(8.58)

1.425

.134

(0.99)

.019

$-.035$

(0.50)

$-.104$

(2.20)

Children's education levels: none, primary, junior secondary, senior secondary, college and higher. Coefficients not shown: mother's age and powers of age, married, child's age and powers of age, religion, school availability, ordered-probit cut points.

The effects of economic status on fertility are variable, with positive influences apparent in Pakistan and Malaysia but negative effects in the Philippines and Thailand. In Taiwan, the clearest contrast is between households with spouses who work in agriculture and all other households. With respect to children's educational attainment, we see uniformly positive effects of higher status. If atten- 
Table 5 Children Ever Born and Level of Schooling: Malaysian Family Life Survey, 1988

Children Ever Born

Children's Level

$\mathrm{N}=858$ of Schooling

\begin{tabular}{lrr} 
& $\mathbf{N}=\mathbf{8 5 8}$ & $\mathbf{N = 4 , 2 2 2}$ \\
\hline $\begin{array}{l}\text { Child's Sex } \\
\text { Girl }\end{array}$ & & -.204 \\
( |z|-statistic) & & $(5.55)$ \\
Woman's Schooling & & \\
Primary & -.294 & .354 \\
& $(3.55)$ & $(8.42)$ \\
Secondary or higher & -.637 & .470 \\
& $(4.30)$ & $(5.34)$ \\
Spouse's Schooling & & \\
Primary & .108 & .098 \\
& $(1.09)$ & $(1.92)$ \\
Secondary or higher & -.244 & .338 \\
& $(1.72)$ & $(4.18)$ \\
Household possessions & & .234 \\
Index & .200 & $(4.89)$ \\
& $(2.35)$ & -.008 \\
Index, squared & -.014 & $(1.83)$ \\
Residence & $(1.81)$ & \\
Urban & & .119 \\
& -.056 & $(2.95)$ \\
Woman's Cohort & $(0.64)$ & -.041 \\
Born before 1950 & & $(0.33)$ \\
Born 1950-1955 & -.346 & -.088 \\
& $(0.90)$ & $(0.75)$ \\
\hline Children's & -.294 &
\end{tabular}

Children's education levels: none, any primary, any secondary, any tertiary.

Coefficients not shown: mother's age and powers of age, married, child's age and powers of age, ethnicity, school availability, ordered-probit cut points.

tion were restricted to the Philippines and Thailand, improvements in these dimensions of economic status would evidently have the potential to induce a quantityquality tradeoff. In other settings (e.g., Pakistan), we can identify no such potential.

Cohort effects. The clearest evidence of cohort effects is seen in the Taiwan sibling analysis (Table 9), which identifies time trends-associated with the birth cohort of the respondent's mother-acting to reduce fertility and increase 
Table 6 Children Ever Born and Years of Schooling: Philippines DHS, 1993

Children Ever Born

Children's Years

$\mathrm{N}=15,029$

of Schooling

$\mathrm{N}=14,290$

Child's Sex

Girl

( |z|-statistic)

Woman's Schooling

Secondary

$-.363$

(14.08)

$-.829$

(12.11)

Higher

Spouse's Schooling

Secondary

Higher

(7.47)

Household possessions

Index

(4.17)

Index, squared

$-.002$

$-.014$

(0.83)

Residence

$-.009$

.010

Town

(0.28)

$(0.37)$

$-.041$

$-.014$

Small city

(1.60)

$-.190$

(5.23)

Woman's Cohort

.083

Born 1950-1955

(1.75)

$-.008$

$(0.26)$

Coefficients not shown: mother's age and powers of age, married, child's age and powers of age, ordered-probit cut points.

children's educational investments. We also included a dummy variable distinguishing children born after 1956 from those born earlier, in order to see whether the 1968 increase in the mandatory level of schooling had any effect. This variable did not prove to be significant (results not shown). 
Table 7 Children Ever Born and Years of Schooling: Thailand DHS, 1987

Children Ever Born

$\mathrm{N}=6,760$

Child's Sex

Girl

( $|z|$-statistic)

Woman's Schooling

Primary

$-.270$

(5.91)

Secondary

$-.515$

(7.96)

Higher

$-.981$

(11.58)

Spouse's Schooling

Secondary

$-.250$

(6.60)

Higher

$-.317$

(4.78)

Household possessions

Index

$-.228$

(7.59)

.019

(5.75)

Residence

Other urban

$-.173$

(4.56)

$-.239$

(6.64)

Woman's Cohort

Born before 1950

.135

(1.23)

.008

(0.12)
Children's Years

of Schooling

$\mathrm{N}=8,196$

$-.012$

(0.52)

.457

(12.06)

.680

(10.73)

.707

(7.72)

.310

(7.97)

.211

(2.86)

.129

(4.55)

.002

(0.55)

.169

(4.50)

.271

(7.67)

.169

(2.45)

.065

(1.46)

Coefficients not shown: mother's age and powers of age, married, child's age and powers of age, ordered-probit cut points. 
Table 8 Children Ever Born and Level of Schooling: Taiwan Women and Family Survey 1989

Children Ever Born

$\mathrm{N}=3,803$

Child's Sex

Girl

( |z|-statistic)

Woman's Schooling

Completed Primary

$-.207$

(3.88)

Some Secondary

$-.522$

(7.23)

Completed Secondary or Higher

(13.21)

Spouse's Schooling

Completed Primary

(2.67)

.079

(6.60)

$-.091$

(1.20)

Own Home

.120

(3.17)

Spouse's Occupation

Prof./Tech./Teacher

$-.217$

(2.35)

$-.144$

(1.63)

$-.148$

(1.79)

$-.121$

(1.65)

$-.137$

(1.48)

$-.217$

(3.50)

$-.261$

(3.00)

$-.159$

(4.03)

$-.051$

(0.68)
$-.114$

(4.77)

.274

(8.80)

.305

$(5.88)$

.088

(1.61)

.311

(8.77)

.483

(10.14)

(13.58)

.042

(1.54)

.084

(1.17)

.008

(0.12)

$-.022$

(0.35)

.078

(1.41)

$-.162$

(2.42)

$-.117$

(2.33)

$-.241$

(4.59)

(0.42)

Children's education levels: none, some primary, completed primary, some secondary, completed secondary, university.

Omitted category for spouse's occupation is agriculture.

Coefficients not shown: mother's age and powers of age, married, child's age and powers of age, dummies for missing husband's education and occupation, ordered-probit cut points. 
Table 9 Number of Siblings and Their Level of Schooling: Taiwan Women and Family Survey 1989

\begin{tabular}{|c|c|c|}
\hline & $\begin{array}{r}\text { Children Ever Born } \\
\text { to Respondent's Mother } \\
\mathrm{N}=3,796\end{array}$ & $\begin{array}{r}\text { Siblings' and } \\
\text { Respondent's Level } \\
\text { of Schooling } \\
\mathbf{N}=21,304 \\
\end{array}$ \\
\hline \multicolumn{3}{|l|}{ Child's Sex } \\
\hline $\begin{array}{l}\text { Girl } \\
\text { (|z|-statistic) }\end{array}$ & & $\begin{array}{r}-.534 \\
(34.37)\end{array}$ \\
\hline \multicolumn{3}{|l|}{ Mother's Schooling } \\
\hline Completed Primary & $\begin{array}{l}-.108 \\
(2.17)\end{array}$ & $\begin{array}{r}.374 \\
(16.41)\end{array}$ \\
\hline Any Secondary or Higher & $\begin{array}{l}-.292 \\
(3.35)\end{array}$ & $\begin{array}{r}.709 \\
(16.43)\end{array}$ \\
\hline \multicolumn{3}{|l|}{ Father's Schooling } \\
\hline Completed Primary & $\begin{array}{r}.052 \\
(1.16)\end{array}$ & $\begin{array}{r}.531 \\
(26.66)\end{array}$ \\
\hline Any Secondary or Higher & $\begin{array}{r}.028 \\
(0.40)\end{array}$ & $\begin{array}{r}.798 \\
(25.20)\end{array}$ \\
\hline \multicolumn{3}{|l|}{ Father's Occupation } \\
\hline Prof./Tech./Teacher & $\begin{array}{l}-.098 \\
(0.93)\end{array}$ & $\begin{array}{r}.551 \\
(11.09)\end{array}$ \\
\hline Admin./Manager & $\begin{array}{l}-.053 \\
(0.60)\end{array}$ & $\begin{array}{r}.734 \\
(17.84)\end{array}$ \\
\hline Clerical & $\begin{array}{l}-.001 \\
(0.02)\end{array}$ & $\begin{array}{r}.551 \\
(17.13)\end{array}$ \\
\hline Sales & $\begin{array}{l}-.098 \\
(1.68)\end{array}$ & $\begin{array}{r}.356 \\
(13.59)\end{array}$ \\
\hline Service & $\begin{array}{l}-.066 \\
(0.71)\end{array}$ & $\begin{array}{r}.252 \\
(5.97)\end{array}$ \\
\hline Prod./Trans. Worker & $\begin{array}{l}-.108 \\
(2.09)\end{array}$ & $\begin{array}{r}.127 \\
(5.50)\end{array}$ \\
\hline Soldier, other & $\begin{array}{l}-.512 \\
(4.90)\end{array}$ & $\begin{array}{r}.848 \\
(15.89)\end{array}$ \\
\hline \multicolumn{3}{|l|}{ Residence at Age 15} \\
\hline Urban & $\begin{array}{l}-.163 \\
(4.51)\end{array}$ & $\begin{array}{r}.248 \\
(15.14)\end{array}$ \\
\hline \multicolumn{3}{|c|}{ Subjective Adequacy of Income } \\
\hline Adequate & $\begin{array}{l}-.052 \\
(1.33)\end{array}$ & $\begin{array}{r}.271 \\
(15.59)\end{array}$ \\
\hline Well Off & $\begin{array}{l}-.045 \\
(0.60)\end{array}$ & $\begin{array}{r}.485 \\
(14.14)\end{array}$ \\
\hline
\end{tabular}


Table 9 (continued)

\begin{tabular}{lrr}
\hline & $\begin{array}{r}\text { Children Ever Born } \\
\text { to Respondent's Mother } \\
\text { N=3,796 }\end{array}$ & $\begin{array}{r}\text { Siblings' and } \\
\text { Respondent's Level } \\
\text { of Schooling } \\
\text { N=21,304 }\end{array}$ \\
\hline Mother's Birth Cohort & & \\
Born 1910-14 & .063 & .233 \\
Born 1915-19 & $(0.75)$ & $(6.35)$ \\
& -.031 & .455 \\
Born 1920-24 & $(0.41)$ & $(13.39)$ \\
& -.091 & .580 \\
Born 1925-29 & $(1.20)$ & $(17.26)$ \\
Born 1930-34 & -.379 & .713 \\
& $(5.09)$ & $(21.18)$ \\
Born 1935-39 & -.533 & .764 \\
Born 1940-44 & $(6.84)$ & $(21.51)$ \\
& -.756 & .770 \\
& $(8.71)$ & $(18.87)$ \\
& -.840 & .683 \\
& $(6.02)$ & $(9.93)$ \\
\hline
\end{tabular}

Respondent's and siblings' education levels: none, completed primary, any secondary, any higher. Omitted category for father's occupation is agriculture; omitted category for birth cohort is mother born before 1910 .

Coefficients not shown: dummies for missing father's education and occupation, missing mother's age and education, missing income adequacy, ordered-probit cut points.

\section{Summary}

Although the results above are drawn from a heterogeneous collection of Asian countries, they display an impressive consistency. In drawing conclusions from these results, we are intrigued by the central role played by women's education. Much attention in the fertility literature has been given to the effect of women's education, but with a few important exceptions (Lillard and Willis 1994; Behrman 1997; Schultz 1998; Lam and Duryea 1999) less consideration has been given to its influence on the education of children.

Human capital theory can offer a general characterization of the relationship between the education of the mother and that of her children, but is less 
revealing on the specifics. Usually, the relationship is described as exemplifying the greater efficiencies that are achieved by educated women in home production. This abstract description fails to illuminate the mechanisms.

One could view the connection as reflecting income effects in settings in which better-educated women are much engaged in the labor market, and are therefore better positioned to help meet the costs of schooling. Lam and Duryea (1999) find little direct support for this proposition in Brazil. A related proposition is that better-educated women possess greater bargaining power in the household, and are able to secure a greater share of household resources for their children. Schultz (1998) and Behrman (1997) review the literature, and find a good deal of evidence favoring this view.

Another possibility is that better-educated women are linked to social networks that contain more better-educated members. Through such network ties, women may develop a keener appreciation of the economic benefits of schooling and its non-economic benefits in health and related areas. The information available to educated women may reduce the variance of their perceptions and lessen aversion to risk in making human capital investments. Such network-related information may well be expressed in the regression coefficient of mother's education. Behrman (1997) outlines a similar argument in stressing the informational advantages of educated women and their abilities to cope with change and economic disequilibrium.

An alternative explanation also merits consideration. Women who have been to school themselves are likely, we think, to take a new view of the nature of child care. They may come to believe that their own time must be devoted to such care if their children are to be properly prepared for schooling and supported during the school years. LeVine et al. (1991) report that educated women tend to engage in a different form of interaction with their children, more often employing highly verbal and other time-intensive modes of communication. If this is so, 
then the changed nature of child care would raise the cost of numbers of children, with attendant negative effects on fertility. Perhaps the new norms about proper child care are transmitted to the younger generation of children, who act on them when they enter their own childbearing years. Behrman (1997) suggests that better-educated mothers may provide more vivid "role models" for their children, and research by Lillard and Willis (1994), among others, shows that such intergenerational mechanisms can be empirically important. In all this, the education of the spouse has, it seems, a supportive influence, as does urban residence.

However plausible the proposition about child care may be, for the moment it must remain speculative. One might expect to find some confirmation of the mother's schooling effect in data on maternal time use. Yet, the comprehensive review by Behrman (1997) lists only two studies of mother's schooling and home time use. Both of these lend support to the hypothesis, but more research is clearly required.

\section{CONCLUSION}

The question posed at the outset was how the quantity-quality transition in Asia could have continued as it did, given the negative feedback effects that are inevitably associated with shifts in the supply of educated labor. Had other things been held constant, these supply shifts should have reduced the returns to schooling and weakened the motivation for deeper investments in human capital and for the fertility reductions that facilitate such investments. Although its working are not always evident in the macroeconomic data, this theory appears unassailable.

But in Asia other things were not held constant, and the outcome was that returns to schooling remained high, apart from some recent declines documented for Taiwan and, earlier, for Korea. The macroeconomic forces sustaining these returns include capital accumulation, technological change, and a set of effects associated with trade. None of these influences is well understood, and the de- 
scriptive regressions that we presented could only suggest that the link to trade deserves close attention.

The Asian transition was also propelled by powerful intergenerational forces operating at the level of families. These positive feedbacks, by which the level of schooling invested in one generation encourages deeper schooling investments in the next, also remain poorly understood. They are linked, we believe, to evolving standards of child care that came to require a more intensive use of parental time, and that may have raised the time costs of childrearing. Interestingly, these effects are as clearly visible in the poorest South Asian countries of our sample (Pakistan and Bangladesh) as they are in the richest of the Southeast Asian countries (Taiwan and Thailand). In this respect, at least, there is more commonality among Asian countries than the literature's preoccupation with Asian "tigers" would suggest.

These days, the phrase "Asian tigers" is used ironically, and one wonders whether the current macroeconomic and financial crisis will so shake Asian parents as to put in doubt the future of the quantity-quality transition. The opportunity cost of their children's time in school has surely risen as the income of parents has fallen, and this may bring about a temporary lull in human capital investment. Whether the crisis will permanently alter perceptions of the returns to schooling is another matter. We predict that the returns will be perceived to be diminished but still superior to what can be provided by alternative investments or uses of time. Such predictions are hazardous, because little is known about the nature and biases of perceptions of returns, the role of local labor conditions as against national conditions, and other factors that affect parental views of schooling. This is among the high-priority areas for research. 


\section{Notes}

1 In this paper, we often refer to the concept of "rates of return" to schooling. The concept stems from the idea that schooling is a form of investment, involving both direct and indirect (opportunity) costs, and producing a stream of returns into the future. The rate of return is the discount factor that equates the present value of the stream of returns to the present value of costs. It is analogous to a rate of interest and is commonly expressed in percentage terms.

2 Lack of enrollment data for 1970 limits the Bangladesh case to the 1985 point shown in the graph.

3 Further discussion of the issues can be found in Montgomery and Lloyd (1997) and Montgomery et al. (1998b).

4 See Manski (1992) and Dominitz and Manski (1994a, b) for an application to U. S. labor markets and Montgomery (1998a) for a discussion of the role of social learning in demographic dimensions.

5 We rely on enrollment data from the World Bank's World Development Indicators (1997), which are primarily based on UNESCO data.

6 See Birdsall and Sabot (1994) and Birdsall et al. (1995) for insightful comparisons of Latin American and East Asian schooling policies.

7 As the supply of educated labor increases, the costs of investing in schooling and other forms of human capital may decrease, at least to the extent that costs are dominated by teacher and administrator salaries (Topel 1998). Most studies of returns to schooling assume that the main costs to educa- 
tion are forgone earnings, and therefore miss the impact on returns due to reduced costs on the supply side of schooling.

8 Supporting evidence is cited by Topel (1998), who refers to a dissertation by $\mathrm{H}$. C. Lu that found falling returns to human capital in Taiwan in response to increasing supplies of educated labor.

9 Data not shown. Without denying the magnitude of these increases, Behrman and Schneider (1994b) caution that, when compared to other developing regions, advances in schooling in Asia from the mid-1960s to the late 1980 s were not clearly exceptional.

10 This conclusion has been incorporated in much subsequent work, such as the model of Krusell et al. (1997), who specify a production function for the United States with a much higher elasticity of substitution between unskilled labor and capital equipment than between skilled labor and capital. Their model generates estimates that replicate closely the variation in skilled-unskilled wage differentials from 1963 to 1991.

11 See DiNardo and Pischke (1997) for a skeptical view of the evidence.

12 Young (1995) and Krusell et al. (1997) have emphasized the importance of refined measures of capital that allow capital equipment and structures to be distinguished. Their substitutability with skilled labor differs, and some evidence suggests that the price of capital equipment has declined relative to the price of structures, thus preventing the two from being aggregated into a composite measure of capital. In addition, the quality of capital equipment has improved, especially in computers. One wonders whether the assumptions used to derive efficiency units of capital might, from the competing perspective, be viewed instead as representing technological change. 
13 See Birdsall and Sabot (1994), Birdsall et al. (1997), and Krueger (1990).

14 Using data from eight OECD countries, Keller (1997) finds evidence that the benefit derived from foreign $R \& D$ in an industry is 50-95 percent of the productivity effect of domestic R\&D. Coe and Helpman (1993), in a much-cited study of 22 developed-country economies, found that R\&D investment by trading partners had a large effect on total factor productivity. Perhaps the most interesting finding for present purposes is that foreign $R \& D$ capital stocks appear to have had particularly large effects on the smaller countries in the Coe and Helpman sample. Also see Eaton and Kortum $(1994,1995)$ for additional work in this vein.

15 Supporting evidence is provided by Feenstra and Hanson (1995) and Feliciano (1995) for Mexico after its trade liberalization in the 1990s. Also see Londono de la Cuesta (1990) and Davis (1992) for related Latin American studies. Milner and Wright (1998) concluded that wages and employment in Mauritius increased for skilled labor after trade liberalization.

16 The data are drawn from Summers and Heston (1991).

17 The data are drawn from Barro and Lee (1996).

18 Also taken from Summers and Heston (1991).

19 Recent papers by labor economists commenting on the growth literature (Krueger and Lindahl 1998; Topel 1998) caution that the international data on the educational levels of workers are prone to measurement error, a potential weakness of the Barro-Lee data that we employ.

20 A number of additional specifications, whose results are not reported here, have been explored. We have examined different specifications for adult 
educational attainment ratios and capital per worker; we have also investigated whether measures of school quality (Barro and Lee 1996) made an appreciable difference. Although the alternative regressions differ from those of Table 1 in the details, we uncovered no important substantive differences.

21 See Behrman (1997) for an extensive review.

\section{References}

Autor, David H., Lawrence F. Katz, and Alan B. Krueger. 1997. “Computing inequality: Have computers changed the labor market?" NBER Working Paper 5956, National Bureau of Economic Research, Cambridge, Massachusetts.

Barro, Robert J. and Jong-Wha Lee. 1996. "International measures of schooling years and schooling quality." American Economic Review 86(2): 218223.

Bartel, Ann P. and Frank Lichtenberg. 1987. "The comparative advantage of educated workers in implementing new technology." Review of Economics and Statistics 519(1): 1-11.

Behrman, Jere R. 1988. "Intra-household allocation of nutrients in India.” $O x$ ford Economic Papers 40: 32-54.

- 1997. "Mother's schooling and child education: A survey." Mimeo, Department of Economics, University of Pennsylvania.

Behrman, Jere R. and Ryan Schneider. 1994. “An international perspective on schooling investments in the last quarter century in some fast-growing East and Southeast Asian countries." Asian Development Review 12(2): 1-50.

Berman, Eli, John Bound, and Zvi Griliches. 1994. "Changes in the demand for skilled labor within U.S. manufacturing: Evidence from the Annual Sur- 
vey of Manufactures.” Quarterly Journal of Economics 109(437): 367397.

Berman, Eli, John Bound, and Stephen Machin. Forthcoming. "Implications of skill-biased technological change: International evidence." Quarterly Journal of Economics.

Berndt, Ernst R., Catherine J. Morrison, and Larry S. Rosenblum. 1992. "Hightech capital formation and labor composition in U.S. manufacturing industries: An exploratory analysis." NBER Working Paper 4010, National Bureau of Economic Research, Cambridge, Massachusetts.

Birdsall, Nancy, David Ross, and Richard Sabot. 1995. "Inequality as a constraint on growth in Latin America," in D. Turnham, C. Foy, and G. Larrain (eds.), Social Tensions, Job Creation and Economic Policy in Latin America, pp. 175-207. Paris: OECD.

- 1997. "Education, growth and inequality," in Nancy Birdsall and Frederick Jaspersen (eds.), The Pathways to Growth: Comparing East Asia and Latin America. Washington, D.C.: Inter-American Development Bank.

Birdsall, Nancy and Richard Sabot. 1994. "Inequality, exports and human capital in East Asia: Lessons for Latin America," in Colin I. Bradford (ed.), Redefining the State in Latin America, pp. 153-171. Paris: OECD.

Choi, Kang-Shik. 1993. "Technological change and educational wage differentials in Korea." Discussion Paper 698, Economic Growth Center, Yale University.

Coe, David T. and Elhanan Helpman. 1993. "International R\&D spillovers." NBER Working Paper 4444, National Bureau of Economic Research, Cambridge, Massachusetts.

Davis, Donald R. 1996. "Trade liberalization and income distribution.” NBER Working Paper 5693, National Bureau of Economic Research, Cambridge, Massachusetts. 
Davis, Steven J. 1992. "Cross-country patterns of change in relative wages." NBER Working Paper 4085, National Bureau of Economic Research, Cambridge, Massachusetts.

DiNardo, John E. and Jorn-Steffen Pischke. 1997. "The returns to computer use revisited: Have pencils changed the wage structure too?" Quarterly Journal of Economics 112(1): 291-303.

Dominitz, Jeff and Charles F. Manski. 1994a. "Eliciting student expectations of the returns to schooling." Unpublished paper, Institute for Social Research, University of Michigan.

. 1994b. "Using expectations data to study subjective income expectations." Unpublished paper, Institute for Social Research, University of Michigan.

Eaton, Jonathan and Samuel Kortum. 1994. "International patenting and technology diffusion.” NBER Working Paper 4931, National Bureau of Economic Research, Cambridge, Massachusetts.

- 1995. "Engines of growth: Domestic and foreign sources of innovation." NBER Working Paper 5207, National Bureau of Economic Research, Cambridge, Massachusetts.

Evenson, Robert E. and Lakhwinder Singh. 1997. "Economic growth, international technological spillovers and public policy: Theory and empirical evidence from Asia." Discussion Paper 777, Economic Growth Center, Yale University.

Feenstra, Robert and Gordon Hanson. 1995. "Foreign investment, outsourcing and relative wages," in Robert Feenstra, Gene M. Grossman, and Douglas A. Irwin (eds.), The Political Economy of Trade Policy: Papers in Honor of Jagdish Bhagwati. Cambridge, Massachusetts: MIT Press.

Feliciano, Zadia. 1995. "Workers and trade liberalization: The impact of trade reforms in Mexico on wages and unemployment." Mimeo, Economics Department, Queens College. 
Fields, Gary S. 1994. "Changing labor market conditions and economic development in Hong Kong, the Republic of Korea, Singapore, and Taiwan, China." The World Bank Economic Review 8(3): 395-414.

Freeman, Richard B. 1979. "The effect of demographic factors on age-earnings profiles.” Journal of Human Resources 14(3): 290-318.

Funkhouser, Edward. 1998. "Changes in the returns to education in Costa Rica." Journal of Development Economics 57: 289-317.

Gindling, T. H., Marsha Goldfarb, and Chun-Chig Chang. 1995. "Changing returns to education in Taiwan: 1978-91." World Development 23(2): 343-356.

Hamermesh, Daniel. 1986. "The demand for labor in the long run," in Orley Ashenfelter (ed.), Handbook of Labor Economics, Volume I. Amsterdam: Elsevier Science.

Huang, Fung-Mey. 1997. "Education, earning and fertility in Taiwan." Paper presented at the conference on "Population and the Asian Economic Miracle," Program on Population, East-West Center, Honolulu.

1998. "The effect of demographic factors and labor demand on the structure of wages in Taiwan 1978-1997." Paper presented at the conference on "Economic Aspects of Demographic Transition: The Experience of Asian-Pacific Countries," Institute of Economics, Academia Sinica, Taipei, Taiwan.

Johnson, George. 1997. "Changes in earnings inequality: The role of demand shifts." Journal of Economic Perspectives 11(2): 41-54.

Katz, Lawrence F. and Kevin M. Murphy. 1992. "Changes in relative wages, 1963-1987: Supply and demand factors." Quarterly Journal of Economics 107(1): 35-78.

Keller, Wolfgang. 1997. "Trade and the transmission of technology." NBER Working Paper 6113, National Bureau of Economic Research, Cambridge, Massachusetts. 
Kim, Dae-Il and Robert H. Topel. 1995. "Labor markets and economic growth: Lessons from Korea's industrialization, 1970-1990." in Richard B. Freeman and Lawrence F. Katz (eds.), Differences and Changes in Wage Structures, pp. 227-264. Chicago: National Bureau of Economic Research.

Kim, Jong-Il and Lawrence J. Lau. 1994. "The sources of economic growth of the East Asian newly industrialized countries." Journal of the Japanese and International Economies 8: 235-271.

Krueger, Alan B. and Mikael Lindahl. 1998. "Education for growth: Why and for whom." Mimeo, Department of Economics, Princeton University.

Krueger, Anne O. 1990. "The relationship between trade, employment and development." in T. Paul Schultz and Gustav Ranis (eds.), The State of Development Economics: Progress and Perspectives. Cambridge, Massachusetts: Basil Blackwell.

Krusell, Per, Lee E. Ohanian, Jose-Victor Rios-Rull, and Giovanni L. Violante. 1997. "Capital-skill complementarity and inequality: A macroeconomic analysis.” Research Department Staff Report 239, Federal Reserve Bank of Minneapolis.

Lam, David and Suzanne Duryea. 1999. "Effects of schooling on fertility, labor supply, and investments in children." Journal of Human Resources 34(1): 160-192.

Lawrence, Robert and Matthew Slaughter. 1993. "International trade and American wages in the 1980s: Giant sucking sound or small hiccup?" in Brookings Papers on Economic Activity: Microeconomics, Volume 2, pp. 161-225. Washington, D.C.: Brookings Institution Press.

Leamer, Edward E. 1998. "In search of Stolper-Samuelson linkages between international trade and lower wages," in Susan M. Collins (ed.), Imports, Exports and the American Worker. Washington, D.C.: Brookings Institution Press. 
LeVine, Robert A., Sarah E. LeVine, Amy Richman, F. Medardo Tapia Uribe, Clara Sunderland Correa, and Patrice M. Miller. 1991. "Women's schooling and child care in the demographic transition: A Mexican case study." Population and Development Review 17(3): 459-496.

Lillard, Lee A. and Robert J. Willis. 1994. "Intergenerational educational mobility: Effects of family and state in Malaysia." The Journal of Human Resources 29(4): 1126-1166.

Londono de la Cuesta, Juan Luis. 1990. "Income distribution during the structural transformation: Colombia 1938-1988." Ph.D. thesis, Department of Economics, Harvard University.

Manski, Charles F. 1992. "Adolescent econometricians: How do youth infer the returns to schooling?" in Charles Clotfelter and Michael Rothschild (eds.), Studies in Supply and Demand of Higher Education. Chicago: University of Chicago Press.

Mason, Andrew. 1993. "Demographic change, household resources and schooling decisions," in Naohiro Ogawa, Gavin Jones, and Jeffrey Williamson (eds.), Human Resources in Development along the Asia-Pacific Rim, pp. 259-282, Singapore: Oxford University Press.

Mason, Andrew and Burnham O. Campbell. 1993. "Demographic change and the Thai economy: An overview." in Burnham O. Campbell, Andrew Mason, and Ernesto M. Pernia (eds.), The Economic Impact of Demographic Change in Thailand, 1980-2015, pp. 1-52. Honolulu, Hawaii: University of Hawaii Press.

Mazumdar, Dipak. 1993. "Labor markets and adjustment in open Asian economies: The Republic of Korea and Malaysia." The World Bank Economic Review 7(3): 349-380.

Milner, Chris and Peter Wright. 1998. "Modelling labour market adjustment to trade liberalisation in an industrialising economy." Economic Journal 108(447): 509-528. 
Mingat, Alain. 1998. “The strategy used by high-performing Asian economies in education: Some lessons for developing countries." World Development 26(4): 695-715.

Montgomery, Mark R. 1998. "Learning and lags in mortality perceptions," in Mark R. Montgomery and Barney Cohen (eds.), From Death to Birth: Mortality Decline and Reproductive Change. Washington D.C.: National Academy Press.

Montgomery, Mark R., Kathleen Burke, and Edmundo Paredes. 1997. "Measuring living standards with DHS data." Paper presented at the Annual Meeting of the Population Association of America, Washington, D.C.

Montgomery, Mark R. and Cynthia B. Lloyd. 1997. "Excess fertility, unintended births, and children's schooling." Policy Research Division Working Paper 100, Population Council, New York.

Montgomery, Mark R., Cynthia B. Lloyd, Paul Hewett, and Patrick Heuveline. 1998. "The consequences of imperfect fertility control for children's survival, health and schooling." Demographic and Health Surveys Analytical Reports 7, Macro International, Inc., Calverton, Maryland.

Mundle, Sudpito. 1998. "Financing human development: Some lessons from advanced Asian countries." World Development 26(4): 659-672.

Nelson, Richard R. and Howard Pack. 1998. "The Asian miracle and modern growth theory." Mimeo, Department of Economics, Columbia University.

Pack, Howard and John Page. 1994. "Accumulation, exports and growth in the high-performing Asian economies." Carnegie-Rochester Conference Series on Public Policy 40: 199-236.

Parish, William and Robert Willis. 1993. "Daughters, education, and family budgets." The Journal of Human Resources 28(4): 863-898.

Park, Young-Bum, David Ross, and Richard Sabot. 1996. "Educational expansion and the inequality of pay in Brazil and Korea," in Nancy Birdsall and 
Richard Sabot (eds.), Opportunity Foregone: Education in Brazil, pp. 267288, Washington, D.C.: Inter-American Development Bank.

Psacharopoulos, George. 1985. "Returns to education: A further international update and implications." The Journal of Human Resources 20(4): 583611.

- 1994. "Returns to investment in education: A global update." World Development 22(9): 1325-1343.

Ranis, Gustav. 1996. "The trade-growth nexus in Taiwan's development." Discussion Paper 758, Economic Growth Center, Yale University.

Robbins, Donald J. 1994. "Earnings dispersion in Chile after trade liberalization." Paper presented at the Northeast Universities Development Conference, Harvard Institute for International Development, Harvard University.

- 1996. "HOS hits facts: Facts win: Evidence on trade and wages in the developing world." Development Discussion Paper 557, Harvard Institute for International Development, Harvard University.

Rodrik, Dani. 1997. "TFPG Controversies, Institutions and Economic Performance in East Asia." NBER Working Paper 5914, National Bureau of Economic Research, Cambridge, Massachusetts.

Sarel, Michael. 1997. "Growth and productivity in ASEAN countries." IMF working paper, International Monetary Fund, Asia and Pacific Department.

Schultz, T. Paul. 1998. "Why governments should invest more educating girls than boys." Mimeo, Economic Growth Center, Yale University.

Schultz, Theodore W. 1975. "The value of the ability to deal with disequilibria." Journal of Economic Literature 13(3): 827-846.

Stokey, Nancy. 1996. "Free trade, factor returns, and factor accumulation." Journal of Economic Growth 1: 421-447. 
Summers, Robert and Alan Heston. 1991. "The Penn World Tables, Mark 5: An expanded set of international comparisons, 1950-1988." Quarterly Journal of Economics 106: 327-368.

Topel, Robert H. 1998. “Labor markets and economic growth.” Mimeo, Department of Economics, University of Chicago.

Willis, Robert J. 1986. "Wage determinants: A survey and reinterpretation of human capital earnings functions," in Orley C. Ashenfelter and Richard Layard (eds.), Handbook of Labor Economics. Amsterdam: Elsevier Science.

Wood, Adrian. 1995. "How trade hurt unskilled workers." Journal of Economic Perspectives 9: 57-80.

World Bank. 1993. The East Asian Miracle: Economic Growth and Public Policy. Washington, D.C.: Oxford University Press for the World Bank.

World Bank. 1997. World Development Indicators, 1997. Washington, D.C.: World Bank.

Young, Alwyn. 1995. "The tyranny of numbers: Confronting the statistical realities of the East Asian growth experience." Quarterly Journal of Economics 110(3): 641-680. 


\title{
POLICY RESEARCH DIVISION WORKING PAPERS
}

\author{
Recent Back Issues
}

\section{7}

93 James F. Phillips, Fred N. Binka, Martin Adjuik, Alex Nazzar, and Kubaze Frank Adazu, "The determinants of contraceptive innovation: A case-control study of family planning acceptance in a traditional African society."

94 John Bongaarts and Sajeda Amin, "Prospects for fertility decline and implications for population growth in South Asia."

95 Barbara S. Mensch and Cynthia B. Lloyd, "Gender differences in the schooling experiences of adolescents in low-income countries: The case of Kenya."

96 Martin Brockerhoff and Ellen Brennan, "The poverty of cities in the developing world."

97 Carol E. Kaufman, "Reproductive control in South Africa."

98 John Bongaarts, "Trends in unwanted childbearing in the developing world."

99 Mary Arends-Kuenning, "How do family planning workers' visits affect wom- en's contraceptive behavior in Bangladesh?"

100 Mark R. Montgomery and Cynthia B. Lloyd, "Excess fertility, unintended births, and children's schooling."

101 Mary Arends-Kuenning, "The equity and efficiency of doorstep delivery of contraceptives in Bangladesh."

102 Sajeda Amin, Ian Diamond, Ruchira T. Naved, and Margaret Newby, "Transition to adulthood of female factory workers: Some evidence from Bangladesh."

*103 Margaret E. Greene and Ann E. Biddlecom, "Absent and problematic men: Demographic accounts of male reproductive roles."

104 Michael P. Todaro, "Urbanization, unemployment, and migration in Africa: Theory and policy."

105 Geoffrey McNicoll, "Population and poverty: A review and restatement."

\footnotetext{
* No longer available
} 
106 Sajeda Amin and Gilda Sedgh, "Incentive schemes for school attendance in rural Bangladesh."

107 Martin Brockerhoff and Paul Hewett, "Ethnicity and child mortality in subSaharan Africa."

108 Ann E. Biddlecom and Bolaji M. Fapohunda, "Covert contraceptive use: Prevalence, motivations, and consequences."

109 John Bongaarts and Griffith Feeney, "On the quantum and tempo of fertility."

110 Barbara S. Mensch, Daniel Bagah, Wesley H. Clark, and Fred Binka, "The changing social environment for adolescents in the Kassena-Nankana District of northern Ghana: Implications for reproductive behavior."

111 Martin Brockerhoff and Ann Biddlecom, "Migration, sexual behavior, and HIV diffusion in Kenya."

112 Zeba A. Sathar and John B. Casterline, "The onset of fertility transition in Pakistan."

113 Geoffrey McNicoll, "Government and fertility in transitional and post-transitional societies."
114 John Bongaarts, "Fertility and reproductive preferences in post-transitional societies."

115 Fiona Steele, Sajeda Amin, and Ruchira T. Naved, "The impact of an integrated micro-credit program on women's empowerment and fertility behavior in rural Bangladesh."

116 Cynthia B. Lloyd, Barbara S. Mensch, and Wesley H. Clark, "The effects of primary school quality on the educational participation and attainment of Kenyan girls and boys."

117 Sajeda Amin and Cynthia B. Lloyd, "Women's lives and rapid fertility decline: Some lessons from Bangladesh and Egypt."

118 James F. Phillips and Mian Bazle Hossain, "The impact of family planning household service delivery on women's status in Bangladesh."

119 Mark R. Montgomery and John B. Casterline, "Social networks and the diffusion of fertility control." 
120 John Bongaarts, "The fertility impact of changes in the timing of childbearing in the developing world."

121 James F. Phillips, Wendy L. Greene, and Elizabeth F. Jackson, "Lessons from community-based distribution of family planning in Africa."
122 Mark R. Montgomery, "Mortality decline and the demographic response: Toward a new agenda."

123 Mark R. Montgomery, Mary ArendsKuenning, and Cem Mete, "The quantity-quality transition in Asia." 